\title{
The Transformation Process of the University into a Data Driven Organisation and Advantages It Brings: Qualitative Case Study
}

\author{
Ignacio Carnicero *, Cristina González-Gaya (D) and Víctor F. Rosales (D) \\ Construction and Manufacturing Engineering Department, Universidad Nacional de Educación a \\ Distancia (UNED), 28040 Madrid, Spain; cggaya@ind.uned.es (C.G.-G.); victor.rosales@ind.uned.es (V.F.R.) \\ * Correspondence: icarnicer5@alumno.uned.es
}

Citation: Carnicero, I.; González-

Gaya, C.; Rosales, V.F. The

Transformation Process of the

University into a Data Driven

Organisation and Advantages It

Brings: Qualitative Case Study.

Sustainability 2021, 13, 12611.

https://doi.org/10.3390/su132212611

Academic Editors: Carlos Hervás-

Gómez, María Dolores Díaz-Noguera,

Pedro Román-Graván and María de

los Ángeles Domínguez-González

Received: 28 September 2021

Accepted: 9 November 2021

Published: 15 November 2021

Publisher's Note: MDPI stays neutral with regard to jurisdictional claims in published maps and institutional affiliations.

Copyright: (c) 2021 by the authors. Licensee MDPI, Basel, Switzerland. This article is an open access article distributed under the terms and conditions of the Creative Commons Attribution (CC BY) license (https:/ / creativecommons.org/licenses/by/ $4.0 /)$.

\begin{abstract}
The use of data in decision-making has become prevalent in all sectors, including education. The present paper analyses the steps necessary for a university to become a data-driven organisation and the advantages this transformation has to offer, both in teaching and in management. A qualitative case study methodology was used with a thematic inductive analysis with two groups of participants. The results are a methodology for transformation, identifying the barriers that may arise and actions necessary to overcome them and the advantages the use of data has to offer the university.
\end{abstract}

Keywords: university; higher education; data-driven; change management; digitalisation; digital transformation; data; e-learning

\section{Introduction}

The use of data in decision-making has become increasingly widespread in all types of organisations and companies. There are three principle factors that have allowed greater use and analysis of large amounts of data: (1) increased computational capacity, (2) the generation of large volumes of data, and (3) the development of the necessary hardware and software to analyse this data (Minelli et al., 2013).

However, many organisations fail in their attempt to transform themselves into datadriven organisations. According to a survey by McKinsey Digital, almost eight out of 10 participants reported that their organisations initiated a process of digital transformation in recent years but only $14 \%$ believed these initiatives succeeded in achieving improved performance, and only $3 \%$ reported success in sustaining the changes [1].

There has been growing interest in digital transformation across many sectors due to the needs generated by the COVID-19 pandemic [2].

Universities, with students and faculty on campus, have also been impacted by the pandemic, propelling a rapid process of digitalisation, moving from presential to on-line teaching in mere days. However, this has often been a reactive rather than proactive undertaking. Thus, the pandemic has been an accelerant of the digitalisation process (Zelada, 2020).

Over 34,000 documents [3] related to the use of data in organisations in general and universities in particular were analysed in depth to determine the current practices of universities in this area.

From this analysis it was concluded that although there are universities that have made use of data and digitalisation, many others have a long way to go in the use of data both in terms of the education provided to students and the management of the institution (the idea was shared by several members of one of the groups of participants).

The aim of the present work is to identify the steps the Universidad Francisco de Vitoria should undertake in becoming a data-driven organisation, and the advantages this 
transformation has to offer both in terms of teaching and in management as well as the barriers and facilitators for this transformation. Additionally, universities that fail to make full use of their data run the risk of falling behind those that do (in the opinion of several participants in the study).

To contextualise what is currently being done with data within universities, Table 1 outlines some of the data-oriented initiatives of a number of universities.

Table 1. Current use of data in universities and higher-education institutions [4-6].

\begin{tabular}{ccc}
\hline Higher Education Centre/University & Objective & Benefit Obtained \\
\hline Michigan State University & $\begin{array}{c}\text { Identify potential donors and provide a } \\
\text { deep understanding of a student's } \\
\text { potential to donate }\end{array}$ & $\begin{array}{c}\text { The productivity of the director and } \\
\text { assistant director is improved; improved } \\
\text { definition of donor patterns; improves } \\
\text { team productivity; annual labour savings } \\
\text { of USD 34,434 }\end{array}$ \\
\hline
\end{tabular}

Send reward letters to high-achieving students three time per year, and evaluate

24,000 students to determine their

Flinders University of Australia eligibility, a task requiring a great deal of staff dedication

Creation of a technology centre

UNED (Spain)

Concordia University Wisconsin

University of California-Santa Barbara

Arizona State University

University of Maryland-College Park

Predict student success or failure and the need for counselling

Predict the success or failure of students and their need for orientation
Identify students at risk and provide them with assistance

Improve the identification of those who may make donations and encourage them to repeat donations

Improve the identification of who can donate and who can repeat their donations

Improve programming/scheduling of courses
Ulster University, Derry, Northern Ireland
The university now has "Betty the bot"

(Betty the robot) and annually saves more than $1800 \mathrm{~h}$ of staff time.

There has been a notable push to make use of ICT since 1999.

Increase in student retention rates to $82 \%$, a $10 \%$ increase in one year

Saving time and money; exponential increase in annual income from donors

Saving time and money, exponential increase in annual donor income

\section{Use of virtual assistants, voice user interfaces, and virtual reality in engineering laboratories}

Management and oversight of student performance

Detect students who are not doing their assignments or are skipping classes

Early intervention for students at risk of abandonment
A $20 \%$ increase in graduates
Helped narrow achievement gaps for low-income and minority students; improvement of graduation rates; decrease in the time spent by the student until graduation

Helping to reduce differences in performance for low-income and minority students; improved graduation rates; reduction in time taken for students to graduate

Increase in student learning and motivation

Increased graduation rates by helping students with difficulties

Increased graduation rates

A $6 \%$ increase in graduation rates; reduction in differences in performance by low-income and minority students
University of Texas at Austin

Washburn University
Retain students and increase graduation rate
Increased graduation rates 
Table 1. Cont.

\begin{tabular}{ccc}
\hline Higher Education Centre/University & Objective & Benefit Obtained \\
\hline Carlos III University (Madrid) & $\begin{array}{c}\text { Identify students not completing tasks as } \\
\text { required or skipping class }\end{array}$ & Increased graduation rates \\
Sinclair Community College & $\begin{array}{c}\text { Early and precise intervention in security } \\
\text { threats and incidents in the university } \\
\text { network }\end{array}$ & $\begin{array}{c}\text { A more rapid understanding and } \\
\text { response to incidents; increase in network } \\
\text { security; reduction of time dedicated to } \\
\text { investigating incidents }\end{array}$ \\
\hline University of Oregon & $\begin{array}{c}\text { Retain students and increase number of } \\
\text { graduates }\end{array}$ & Increased graduation rates \\
Delaware State University & $\begin{array}{c}\text { Increase in the rate of retention of } \\
\text { advisory best practices }\end{array}$ & $\begin{array}{c}\text { students to 70\%; increase in the number } \\
\text { of students that graduate in 4 years by } \\
\text { 4 percentage points }\end{array}$ \\
\hline
\end{tabular}

The main hypothesis is:

- The key factors in transforming universities into data-driven organisations are the use of technology, the analytical mentality of the university team, leadership (primarily, the rector and their team, with experts in transformation to become data-driven), improved decision-making, and improved data management.

Two other hypotheses are:

- There is significant potential for growth in the use of data by universities with numerous advantages to transformation, both in teaching and in management.

- It is necessary to design and implement a solid and detailed change management plan.

There is an ample bibliography on how to transform a company into a date-driven organisation and data-driven decision-making in general terms [7-23], but there is very limited research into how to transform a university into a data-driven organisation. Although there are publications dealing with data usage by universities, they are focussed on the use of data to improve the personalisation of student learning (that is, using the data generated by LMSs, such as Canvas or Moodle), the use of data to identify students at risk, and student selection. However, no studies were found on how to carry out the transformation to a data-driven organisation nor how to use data in decision-making in universities.

The principal objective of this article is to describe and analyse the process of implementation of data-driven systems in a university, the identification of barriers and facilitators, and the advantages it has to offer.

The bibliography below cites a number of important publications on this area of study.

The principal conclusions of this work are the many advantages transformation can offer in terms of university teaching, management, personnel, and reputation. Although there are also numerous barriers to transformation, the present study describes the steps and actions necessary for successful transformation of a university into a datadriven organisation.

\section{Materials and Methods}

\subsection{Scientific Methodology}

This is a qualitative case study using inductive thematic analysis (following the consolidated criteria for reporting qualitative research-COREQ).

The starting point was the idea that the transformation of a university (specifically the Universidad Francisco de Vitoria-UFV) into a data-driven organisation offers numerous benefits and advantages. Based on this, the available literature was reviewed, defining the objectives and research questions and selecting the participants. These consisted of two groups: one of expert consultants (EC) in the transformation of organisations into data-driven organisations, and another of university directors (UD). The responses of the 
participants were coded, maintaining their literal meanings. After coding, the interpretation process began, grouping the codes into thematic areas. This process was conducted for the responses of both groups (EC and UD). Each response for each question by each of the participants was coded and then assigned a colour code to group the responses by themes. The themes of the responses of expert consultants are labelled EC, and those of the UFV university directors as UD. Thus, the themes arising from question 1 of the expert consultants are labelled as theme EC.1.1, theme EC1.2, etc. Those arising from question 1 of UFV directors are labelled as theme UD.1.1, theme UD.1.2, etc.

The topics based on the responses of the expert consultants were grouped into 6 areas: diagnosis and starting point of the state of the university before beginning the transformation, preparation for the transformation, implementation of the transformation, advantages and optimisation once the university is data driven, other comments of interest of the participants (in strategy, management, on the sector), and previous experience of the consultants in educational entities. These topics, in turn, were grouped into a smaller number of topics based on their similarities, to have a more manageable number of topics.

Along the same line, topics based on the responses of the university managers were grouped into 5 areas: diagnosis and starting point of the state of the university before beginning the transformation, preparation for the transformation, implementation of the transformation, advantages and optimisation once the university is data driven, and other comments of interest from the participants (on strategy, management, on the sector). These topics, in turn, were grouped into a smaller number of topics based on their similarities, to have a more manageable number of topics.

On the ideas of the topics contributed by the expert consultant participants and by the directors of UFV, which step/action that should be included in the methodology to transform a university into a data-driven centre was interpreted.

Subsequently, a theoretical framework was established for the phases of transformation with the following steps: (1) diagnosis and point of departure for the state of the university before the transformation process, (2) preparation for transformation, (3) implementation of the transformation, (4) improvements in the university after the transformation as a data-driven organisation through digital optimisation [24]. The themes derived from the codes were distributed in the four phases of the theoretical framework. The analysis revealed repetitions, overlaps, and interrelations between the themes, which led to a merging of themes. This process was carried out both for the responses of the expert consultant group (EC) and for the university director group (UD).

Finally, the repetitions, overlaps, and interrelations of the groups were analysed to create a single proposal for the transformation of UFV into a data-driven organisation, including the steps to follow, identifying the barriers and facilitators of change and the improvements brought on by this transformation (see Appendix E).

\subsection{Context}

As mentioned above, a qualitative case study method was used for this project, focused on analysing the process of transforming a university into a data-driven organisation, using two work units, one for each group of participants.

The specific university in question was the Universidad Francisco de Vitoria (Madrid, Spain). The strategic plan of the university is posted on its website [25]. According to the strategic plan, part two of the strategy is a project called "Data-driven Decisionmaking" (page 9). This plan is described as such: "to develop and deploy a culture of data-based decision-making. The project includes the development and/or adaptation of systems (understood as tools, work flows and actions) for the capture, storage and access to necessary and high-quality data, when necessary by those who need it. The goal is to extract the value data has to offer to generate a holistic vision that can inform decision-making (at macro and meso levels). The objective is to create a culture in which members of the UFV community understand and use available data in their decision-making (this information can be seen in the Reports 19-21 -from page 59-, 18-19-from page 49- and 17-18 -from page 
47- posted on its website explain the university's commitment to digitalisation in general and the use of data in particular).

\subsection{Criteria for the Inclusion of Participants}

The design of the case study included two units, one for each group of participants.

These participants were included in order to provide information on the process being studied.

The first group of participants included expert consultants with extensive experience in the design and implementation of a process for the transformation of a company in general, and a higher-education institution in particular, into a data-driven organisation. The second group of participants included directors of the Universidad Francisco de Vitoria, and key persons in the intention and implementation of the proposed transformation in the organisation.

The participants in the transformation process were those who worked at the university as well as the experts (external or internal) who participated in the transformation process or were affected by the same:

- University directors who decide and support the implementation;

- ICT area of the university;

- External consultants who support the process and have experience in similar projects in other organisations, including higher-education institutions;

- Middle managers who drive implementation in the university.;

- Final users, both teachers and other university personnel;

- Students, who are impacted by the transformation.

However, the sample consisted of two of these groups: directors (those within the academic community holding positions of responsibility at the university) and external experts from companies that design and implement the transformation process in different types of organisations, including universities.

These two groups of participants were selected because of their specific influence on the execution of the transformation process: the former were those who must believe in and lead the change while the latter were those with the experience in undertaking these types of processes, involving two different and complex spheres: technical knowledge of data management and knowledge of organisations and how to implement cultural changes successfully [26].

The other participants were excluded from the analysis because their role was less relevant than the two groups mentioned (based on the experience of the authors). The impact of these groups on the transformation process may be an interesting line of future research.

\subsection{Sampling Strategies}

A purposeful sampling strategy was used [27], that is, the deliberate selection of the participants in the study.

The 13 directors of the Universidad Francisco de Vitoria were interviewed, as were 14 consultants who were experts in big data and business analytics, the majority with experience in the transformation of higher-education institutions (see Appendix A, Tables A1 and A2).

The number of participants was decided with the intention of achieving a high degree of saturation (saturation is described as the point at which no new data or information is expected to be gained through further qualitative interviews).

The saturation point was estimated following Turner-Bowker et al. (2018) [28]. Using their criteria, the use of $13+14$ participants (27 in total) gave a percentage of saturation of over $99 \%$.

\subsection{Positionality of the Researchers}

The preconceptions of the researchers prior to undertaking the study were the following:

- The key figures in the transformation are the team of university directors and the expert consultants (either internal or external). 
- It is necessary to implement a cultural change that involves the adoption of an analytical mentality by the entire university team.

This research project was motivated by the firm belief that making a university a data-driven organisation will lead to better decision-making, student learning outcomes, and university management in general. This belief is based on the experience of one of the authors in big data and business analytics consulting, implementing change in various organisations and as a team member in the project to transform the Universidad Francisco de Vitoria into a data-driven organisation.

\subsection{Data Collection}

The data was collected during a period of one year from June 2020 to June 2021.

This data was collected by means of personal interviews of approximately one hour in duration and, in some cases, complemented by subsequent meetings to clarify certain points.

\subsection{Design and Methodology of the Interviews}

Two sets of questions were designed, one for each group of participants.

The questions for the university directors were designed by Susana Alonso [29] and one of the authors (Ignacio Carnicero) and were based on their prior experience and experience as members of the project team to transform the Universidad Francisco de Vitoria into a data-driven organisation. The 9 questions were designed to determine, from their perspective, the essential elements in transformation, the motivations for transformation, the advantages of becoming data-driven, whether the teams seems ready for change, the reasons to justify the change, the contribution each of the directors has to offer, difficulties and barriers to change, and how to overcome them. These questions are provided in Appendix C.

The questions posed to the expert consultants were designed by Macarena Estévez (founder and CEO of the business analytics and big data company Conento) and Ignacio Carnicero. The 10 questions focussed on how to take advantage of data in a university; whether it is necessary for the team to have an analytical mentality to take maximum advantage of data, and if so, how to acquire an analytical mentality; what the key areas in transformation are; the difficulties and barriers; the need of the university to be ready for change; whether the support of an external team is necessary; and the reasons to justify the effort to make the change.

Some of the questions for the expert consultants coincided with those for the university directors in order to gain different perspectives on certain points and to analyse common and contrasting points. These questions are provided in Appendix D.

\subsection{Coding and Interview Themes}

This section used the thematic coding methodology of Braun and Clarke (2006) [30].

An in-depth analysis was made of the information gathered in the interviews of both the expert consultants and the UFV directors. Using a thematic analysis method, ideas were identified rather than patterns that repeated through the study.

In this analysis, thematic coding was used to provide a detailed description of the entire set of data in order to identify predominant and important themes. These descriptions were used to ensure the identified, codified, and analysed data were a true and faithful reflection of the content of the entire set of data. This involved a certain loss in depth and complexity while allowing a broader scope for the research.

The codes were created using the literal text of the interviews. This phase of the work consisted of the creation of codes based on the data (the codes identify a characteristics of interest for the research, and refer to the segments or basic elements of the raw material of the research).

The codes and themes were grouped and identified by colour. This was done for the responses of both the expert consultants and the UFV directors. These themes not only 
reflect the data but also an initial interpretation from the perspective of the authors, and were defined, connected, and sometimes combined based on the codes.

The themes or patterns of the data were identified in an ascending or in an inductive manner (see Frith and Gleeson, 2004).

In this interpretive phase, the themes arising from the interviews with the two groups of participants were grouped according to the theoretical framework of the transformation phases mentioned previously:

Diagnostic and starting point of the university prior to beginning the transformation process:

- Preparation for transformation;

- Implementation of the transformation;

- Advantages and optimisation once the university is data-driven;

- Observations of interest by the participants (strategy, management, or the sector).

The various themes identified by the codes were distributed during the theoretical framework phase. The analysis detected repetitions, overlaps, and interrelations that led to themes being grouped together.

This grouping of themes was part of the interpretation of the authors to achieve the objectives of the study, namely, to propose a methodology for the transformation of the university into a data-driven organisation and identify the benefits this transformation has to offer.

Two groups of themes were made, one based on the interviews with the expert consultants, the other on the interviews with UFV directors. Each one represents a first methodology proposal for the transformation into a data-driven university.

Repetitions, overlaps, and interrelations for the first two proposals were analysed in order to produce a single proposal for the transformation of UFV into a data-driven organisation, identifying barriers and facilitators of the change and the improvements achieved in the university through this transformation, indicated in Appendix E of this proposal. The appendixes and the tables refer to the barriers, actions and advantages of transformation noting the themes from which these are drawn for the traceability of the codes, themes and results.

\subsection{Quality Criteria}

In this section, the qualitative criteria by Lincon and Buba [31] were applied.

Of particular importance was the criterion of confirmability, the aim of which is to demonstrate a degree of objectivity of the researchers in the analysis of non-interpretive data, thus avoiding bias, motivation, or personal interest. In this sense, all participants in both groups were sent the coding of their interview to offer them the opportunity to verify that their ideas were reflected accurately.

\section{Results}

The study included 14 participants in the expert consultant group and 13 directors from UFV. The profiles of the participants are provided in Tables A1 and A2 of Appendix A; Tables A3 and A4 of Appendix A provide a description of the work done with the participants: duration of the interview, sending the codes of the interview for review, and whether any other actions were taken.

\section{Description, Explanation, and Interpretation of the Results}

The result of the research project was a methodological proposal on how to transform UFV into a data-driven organisation, as presented in Appendix E.

This methodology was endorsed by the group of expert consultants with experience in data-driven transformations, their advantages, and their implementation (in the highereducation sector and others), and a group of UFV directors with an in-depth knowledge of university operations and the drivers of the transformation project (given that the transformation process was instigated within UFV and they were fully aware of the project). 
In this line, the results were enhanced by the fact that the UFV directors recognised the need to make use of data and certain skills, both for the implementation of the transformation process and the benefits they offer (the themes that mention these points are: UD.1.1, UD.1.4, UD.1.5, from UD.3.1 to DE.3.6).

The proposed methodology for the transformation was classified into the following phases (after the coding of the data and grouping into themes, these were classified within the 4 phases as an interpretation of the authors based on previous studies of the digital transformation of organisations and their own experience):

(1) diagnostic and starting point of the university prior to beginning the transformation process, (2) preparation for transformation, (3) implementation of the transformation, (4) advantages to and optimisation of the university as a data-driven organisation.

The following were the most salient points of the diagnostic phase: to conduct a diagnostic of the manner of working (planning, processes, reflection); identify the appropriate profiles within the university for the transformation, and verify attitudes and preparation and the degree of importance given to the notion of transformation by the management team as a whole; conduct a diagnostic of the analytical mentality of the university team; and analyse the current technical state of transformation at the start of the project.

Regarding the second phase, (preparation for transformation), the following points were highlighted: to define the team managing the project (managing and coordinating change); design an action plan that includes clear objectives, a complete budget of the entire change process, and gradual transformation; define the objectives of the transformation with university personnel (humanise the process of transformation); preparation of the team to face and accept the cultural change that transformation supposes, anticipating possible resistance and using leverage to move forward; provide training in management for directors, as well as training in the use of tools, technology, and data analysis for all users; and define/review/update processes to ensure they are logical and coherent and can be assisted using data.

Another result was the definition of what the two groups consider to be critical variables for transformation. following:

Both groups of participants agreed that critical variables for transformation are the

- To invest in the necessary and appropriate technology: usable and accurate information, artificial intelligence, single data lake, user experience tools, storage systems, technological architecture, and hardware;

- To instil in the university team an analytical mentality for all data users. The analytical mentality consists of the capacity for data analysis and confidence in data, the ability to access, understand, work with, and analyse data and make decisions based on that analysis, trusting in the data. The analytical mentality supposes a cultural change. To implement this change, prior knowledge is required (mathematics, tools), as well as training (pedagogy) adapted to the different positions and training in workshops to acquire specific competences with support, transmitting confidence in data through quick wins, feeling that an analytic mentality helps filter a great deal of information reaching users. It is also very important to have adequate tools for data processing and visualisation to facilitate the use of data.

Leadership and data-based decision-making: Regarding leadership, some participants considered that this was the most important factor. Here, leadership refers to the rector and their management team, who must feel and communicate in first person the importance of the transformation and who are key figures in its top-down implementation.

Improved data management: This means to integrate internal and external data networks, creating new data, accessibility, governance, quality and reliability of data, ethics, and adaptation of processes for the use of data.

Another result was the proposal to create a team to manage the transformation project (see Figure 1); this was considered a critical variable by some of the participants. The project management team would lead, drive, and coordinate the project in all its dimensions: 
technical, change management, motivational, budgeting, etc. The team would include the following:

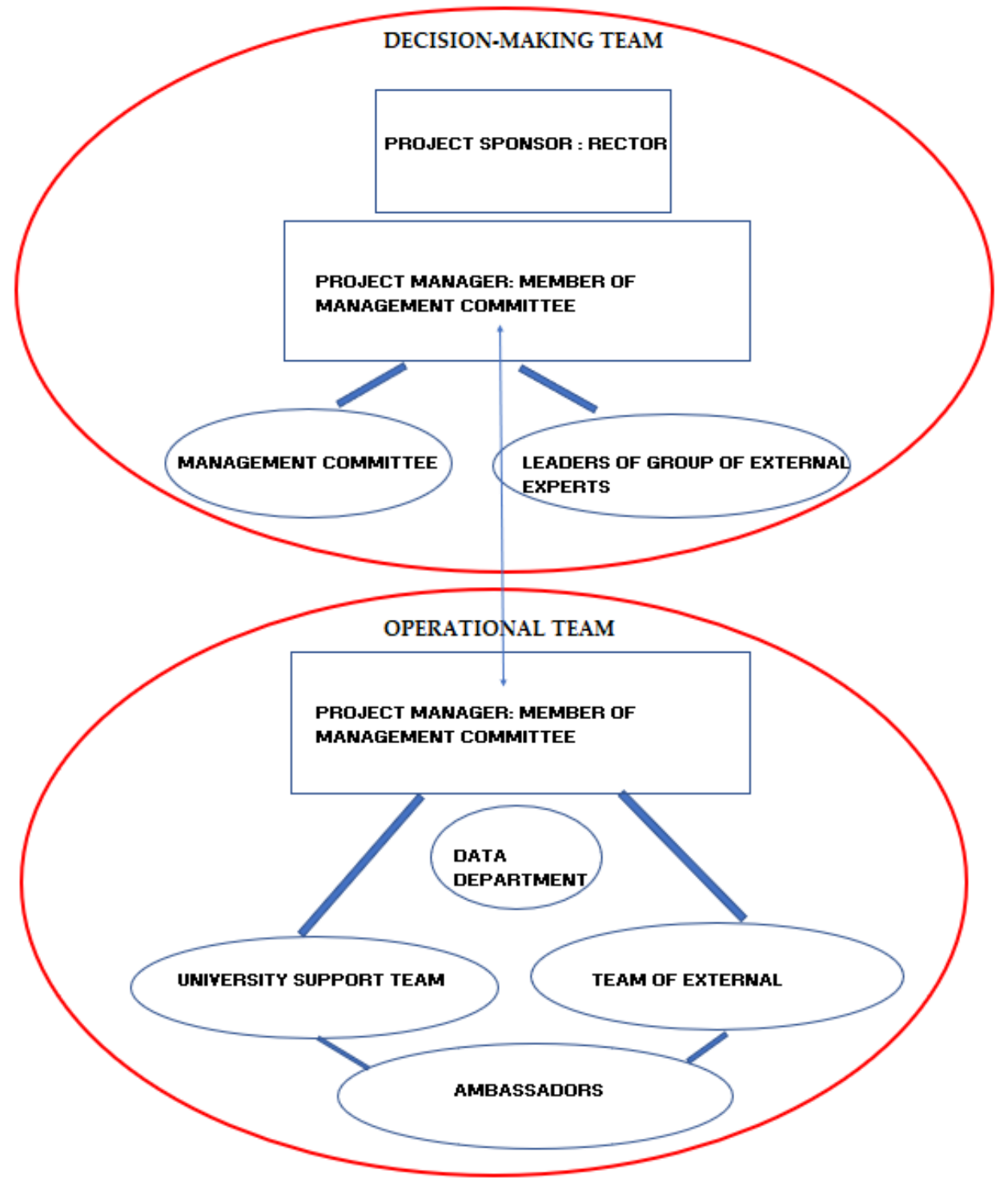

Figure 1. Project team.

- The rector as sponsor of the project.

- Project manager (member of the management committee), who must have in-depth knowledge of the operation of the university (priorities, processes, areas, etc.) and a degree of technical knowledge; deep technical knowledge is not necessary but enough technical know-how to act as an intermediary between the technical staff and the management team of the university is required. It is also essential to believe firmly in the need for and benefits of transformation.

- Management committee: driving the project forward in each of its areas. Initial groundwork is necessary for the mentalisation and training of committee members in order for them to be the drivers and ambassadors of the transformation project.

- Experts in transformation and technical/technological aspects (internal UFV personnel with the assistance of external experts, especially during the launch of the transformation project, as there is a lack of experienced UFV staff at that moment). These specific profiles are data science, data engineering, expert in user experience, and chief data officer, but also with experience in organisational change preferably in higher-education institutions. 
- Support team of the university: Technical personnel and those with in-depth knowledge of the university are part of the project team.

- Ambassadors: support and implementation, natural leaders convinced of the benefits of change and leaders in their areas.

- Data department: consisting of specialists who provide support for developing an analytic mentality, answering questions, providing training, and helping to define the controls, protocols, tools, and access to the necessary data for each area.

One interesting outcome was the proposal to create a visualisation tool, considered a critical variable by one of the participants. This tool must be reliable, user-friendly, and pedagogical, permitting data to be analysed and to draw conclusions. It must also be available to the entire team but with different levels of use depending on positions and profiles.

Other results of the research were the barriers to this type of transformation. Specifically, 26 barriers were identified, indicated in Table 2 (the table shows the themes that give rise to these barriers from the codification of the data), which were classified by the researchers by theme: communication, economics, data management, leadership, mentality, operations, long term results, and technology.

Table 2. Barriers found in the transformation.

\begin{tabular}{|c|c|c|}
\hline Type of Barrier & Barrier & Theme \\
\hline Communication & $\begin{array}{l}\text { Barriers due to poor communication, explaining the } \\
\text { benefits of the project, and being realistic in the time } \\
\text { necessary for execution }\end{array}$ & UD.9.8 \\
\hline Economic & $\begin{array}{l}\text { Economic barriers and assigning the adequate } \\
\text { budget for the project, assuming the initial costs } \\
\text { until results are achieved }\end{array}$ & CE.4.9 \\
\hline Economic & $\begin{array}{l}\text { Barriers due to a lack of financial resources } \\
\text { (inadequate budget), new personnel (internal or } \\
\text { external) requiring investment in time and research. }\end{array}$ & UD.9.4 \\
\hline Economic & Lack of means and knowledge to collect information & CE.4.8 \\
\hline Data management & $\begin{array}{l}\text { To achieve quality and unified data, cleaning and } \\
\text { reprocessing existing data that may be dispersed in } \\
\text { different silos and be of poor quality }\end{array}$ & CE.2.7, CE.4.10 \\
\hline Data management & $\begin{array}{l}\text { Conciliating business objectives with technical } \\
\text { metrics to develop models }\end{array}$ & CE.4.14 \\
\hline Data management & Ethics and privacy issues in the use of data & CE.9.5 \\
\hline Leadership & $\begin{array}{c}\text { Lack of involvement or dedication by top } \\
\text { management }\end{array}$ & CE.4.3 \\
\hline Mentality & $\begin{array}{l}\text { Barriers of mentality/attitude: lack of business } \\
\text { vision, frustration, lack of a change in mindset, } \\
\text { impatience, lack of positive attitude, resistance to } \\
\text { change in mentality, misunderstanding of the } \\
\text { importance of the project, viewing it as low priority }\end{array}$ & UD.9.3 \\
\hline Mentality & Lack of business mentality in the academic world & CE.4.2 \\
\hline Mentality & Clash of mentalities (conservative vs. digital) & CE4.2 \\
\hline Mentality & Generating a great deal of frustration for many & CE.4.13 \\
\hline Mentality & Not a digital-native organisation & CE.4.14 \\
\hline Operational & $\begin{array}{l}\text { Barrier because the team has too much work and } \\
\text { digital transformation requires time (for each person, } \\
\text { area, and position) }\end{array}$ & UD.9.1 \\
\hline
\end{tabular}


Table 2. Cont.

\begin{tabular}{|c|c|c|}
\hline Type of Barrier & Barrier & Theme \\
\hline Operational & $\begin{array}{l}\text { The strategic plan should prioritise steps and clearly } \\
\text { convey the idea that transformation will not be } \\
\text { effective until all the steps are coordinated and thus } \\
\text { avoid frustration. }\end{array}$ & CE.4.6 \\
\hline Operational & $\begin{array}{c}\text { Absence of a clear strategy in all stages of the } \\
\text { transformation }\end{array}$ & CE.4.5 \\
\hline Operational & $\begin{array}{l}\text { Organisational changes due to transformation and } \\
\text { department silos are significant barriers. }\end{array}$ & CE.4.4 \\
\hline Operational & Barriers due to required changes in the organisation & UD.9.7 \\
\hline Operational & Resistance to change & CE.4.1 \\
\hline Long-term results & $\begin{array}{l}\text { The initial results are not sufficiently successful to } \\
\text { generate confidence in the project. }\end{array}$ & CE.4.12 \\
\hline Long-term results & $\begin{array}{l}\text { The initial results take time despite strenuous efforts } \\
\text { being made. }\end{array}$ & CE.4.18 \\
\hline Long-term results & $\begin{array}{l}\text { It is difficult to see the impact of the change in the } \\
\text { short term (it should take } 6 \text { to } 12 \text { months to see } \\
\text { results). }\end{array}$ & CE.4.7 \\
\hline Long-term results & $\begin{array}{l}\text { The transformation process is long and there is a } \\
\text { strong desire for short-term results due to the } \\
\text { significant investment. }\end{array}$ & UD.9.5 \\
\hline Long-term results & $\begin{array}{c}\text { Barrier caused by a failure to take a global view of } \\
\text { the organisation, responding to specific and } \\
\text { particular requests. }\end{array}$ & UD.9.6 \\
\hline Long-term results & $\begin{array}{l}\text { There is a technological and economic barrier in } \\
\text { situations of constant and rapid change for fear that } \\
\text { investments quickly become obsolete. }\end{array}$ & CE.4.17 \\
\hline Long-term results & $\begin{array}{l}\text { Barriers regarding the necessary technology } \\
\text { (knowledge, selection, cost) and having data } \\
\text { separated into unconnected silos }\end{array}$ & UD.9.2 \\
\hline
\end{tabular}

Other results of the research included the identification of actions to overcome barriers and to drive transformation forward. Specifically, 16 actions were identified to overcome barriers, provided in Table 3, classified by theme (according to the criteria of the authors based on their experience): success stories, communication, economics, data management, leadership, mentality, and operations.

Table 3. Action to overcome barriers.

\begin{tabular}{ccc}
\hline Type of Action & Action to Overcome Barriers & Theme \\
\hline Success story & $\begin{array}{c}\text { A way of overcoming barriers is with “quick } \\
\text { wins": small pilot projects with short-term } \\
\text { results that are proof of the advantages of } \\
\text { transformation. }\end{array}$ & $\begin{array}{c}\text { CE.4.16, } \\
\text { CE.5.7, UD.9.16 }\end{array}$ \\
\hline & $\begin{array}{c}\text { The success of the project can be furthered with } \\
\text { good communication of the advantages and } \\
\text { using the right language, sufficient time, and } \\
\text { training with personal support for those having } \\
\text { difficulties, explaining to each stakeholder the } \\
\text { specific benefits to them (teachers, finance, HR). }\end{array}$ & UD.9.15, UD.2.5 \\
\hline
\end{tabular}


Table 3. Cont.

\begin{tabular}{|c|c|c|}
\hline Type of Action & Action to Overcome Barriers & Theme \\
\hline Economic & $\begin{array}{c}\text { The economic benefits of data must be } \\
\text { maximised: They not only generate value for the } \\
\text { university but can also be sold to other } \\
\text { organisations (as some companies are now } \\
\text { doing). }\end{array}$ & CE.4.25 \\
\hline Economic & $\begin{array}{l}\text { Barriers and frustrations can be avoided by } \\
\text { assigning an adequate budget from the start and } \\
\text { dedicating sufficient resources. }\end{array}$ & UD.9.13 \\
\hline Data management & $\begin{array}{l}\text { Create a framework of data management } \\
\text { policies that prioritise unique data with accepted } \\
\text { and quality sources of data. }\end{array}$ & CE.4.24 \\
\hline Data management & $\begin{array}{l}\text { Create a framework of data management } \\
\text { policies that prioritise unique data with accepted } \\
\text { and quality sources of data. }\end{array}$ & CE.4.24 \\
\hline Data management & $\begin{array}{l}\text { Drive the project with quality data and a single } \\
\text { data lake (or interconnected databases) with the } \\
\text { capacity to create OLAP cubes and reports for } \\
\text { data analysis. }\end{array}$ & UD.9.11 \\
\hline Leadership & $\begin{array}{l}\text { University directors can help transformation: } \\
\text { requesting help in driving the project forward } \\
\text { (including in the objectives of transformation), } \\
\text { supporting and driving the project forward, } \\
\text { seeking connections and listening to other areas } \\
\text { in order to further the project together, } \\
\text { accurately identifying KPIs and OKRs of the area } \\
\text { (helping to define and establish flexible controls), } \\
\text { indicating the decisions that can be better made } \\
\text { using data, making clear the needs of the area } \\
\text { that can be supported with data, going from } \\
\text { decision to data (and not from data to decision). }\end{array}$ & $\begin{array}{l}\text { UD.8.2, } \\
\text { UD9.9, } \\
\text { EC3.3 }\end{array}$ \\
\hline Mentality & $\begin{array}{l}\text { With training plans and support by specialists on } \\
\text { the culture and use of data and digital } \\
\text { transformation as a support (not substitute) for } \\
\text { decision-making }\end{array}$ & $\begin{array}{l}\text { CE.4.17, } \\
\text { UD9.17 }\end{array}$ \\
\hline Mentality & $\begin{array}{l}\text { The implementation of an analytic mentality } \\
\text { requires people with experience, introducing } \\
\text { data collection in a natural manner, quick wins, } \\
\text { and implementation by project (with clearly } \\
\text { defined objectives and outputs, data sources, } \\
\text { models of analysis, and the necessary } \\
\text { infrastructure). }\end{array}$ & CE 2.5 \\
\hline Mentality & $\begin{array}{l}\text { Barriers can be overcome by approaching the } \\
\text { project with the right mentality (spirit, } \\
\text { mentalisation, preparation, return on investment } \\
\text { in better management, better work performance, } \\
\text { more focus on priorities) and with an analytic } \\
\text { mentality (digital). }\end{array}$ & UD.9.14 \\
\hline Operational & $\begin{array}{l}\text { For projects with data, first select cases of critical } \\
\text { use for the university. }\end{array}$ & CE.1.4 \\
\hline
\end{tabular}


Table 3. Cont.

\begin{tabular}{|c|c|c|}
\hline Type of Action & Action to Overcome Barriers & Theme \\
\hline Operational & $\begin{array}{l}\text { Define an initial action plan prior to the } \\
\text { implementation: with teams, managers, and } \\
\text { mechanisms for control to monitor } \\
\text { transformation; anticipating difficulties; and } \\
\text { promoting a culture of data, proposing a gradual } \\
\text { implementation and preparing the entire team } \\
\text { (directors and staff) for frustrations. }\end{array}$ & CE.4.23 \\
\hline Operational & $\begin{array}{l}\text { Transformation requires clear objectives and a } \\
\text { time frame to achieve them. }\end{array}$ & CE.4.19 \\
\hline Operational & $\begin{array}{l}\text { Drive the project forward by allowing the team } \\
\text { time, specialised support, and resources (internal } \\
\text { or external), allowing the dedication necessary } \\
\text { for the project by the entire university } \\
\text { community (according to functions and position) } \\
\text { with a fixed weekly commitment of time to the } \\
\text { project. }\end{array}$ & UD.9.10 \\
\hline Operational & $\begin{array}{l}\text { Drive the project forward through adequate } \\
\text { planning of the change process, with gradual } \\
\text { rather than brusque, rapid changes; prioritising } \\
\text { key data in each area involving middle } \\
\text { management in relevant positions, not beginning } \\
\text { in transversal areas but rather in critical areas } \\
\text { (teaching); prioritising the human change that } \\
\text { transformation requires (although working on } \\
\text { the technological aspects in parallel); getting the } \\
\text { transformation project to pursue an agile } \\
\text { methodology with a global vision (not working } \\
\text { on isolated projects), and laying solid } \\
\text { foundations for the transformation process. }\end{array}$ & UD.9.12 \\
\hline Operational & $\begin{array}{l}\text { Resistance to change can be partly overcome } \\
\text { with multidisciplinary work groups. }\end{array}$ & UD.2.4 \\
\hline
\end{tabular}

Regarding the advantages transformation has to offer, Tables 4-9 show the 96 advantages identified. The tables indicate the source of the information (expert consultants (EC) or UFV directors (UD)) and the corresponding theme code. These were classified into the following groups according to the area where the advantages applied (in the opinion of the authors based on their experience): student enrolment ( 9 advantages), teaching ( 45 advantages), economy (2 advantages), strategy (5 advantages), management (20 advantages), personnel (11 advantages), and reputation ( 5 advantages).

Table 4. Advantages of transformation for student enrolment.

\begin{tabular}{ccc}
\hline \multicolumn{1}{c}{ Advantage } & Theme & Source \\
\hline $\begin{array}{c}\text { Optimisation models for the website to } \\
\text { increase conversion }\end{array}$ & CE.1.1 & CONSULTANTS E. \\
\hline $\begin{array}{c}\text { Recruitment of new students, especially } \\
\text { international students, etc. }\end{array}$ & CE.1.1 & CONSULTANTS E. \\
\hline $\begin{array}{c}\text { Predictive models in forecasting campaigns } \\
\text { to recruit new students }\end{array}$ & CE.1.1 & CONSULTANTS E. \\
\hline $\begin{array}{c}\text { Better communication of the academic } \\
\text { programmes, better adaptation of academic } \\
\text { programmes to the demands of the market }\end{array}$ & CE.7.2 & CONSULTANTS E. \\
\hline
\end{tabular}


Table 4. Cont.

\begin{tabular}{ccc}
\hline Advantage & Theme & Source \\
\hline $\begin{array}{c}\text { Better use of advertising to maximise } \\
\text { recruitment of students }\end{array}$ & CE.10.2 & CONSULTANTS E. \\
\hline $\begin{array}{c}\text { Prioritisation of calls to the call centre based } \\
\text { on the probability of recruiting new students }\end{array}$ & CE.1.1, CE.10.2 & CONSULTANTS E. \\
\hline $\begin{array}{c}\text { Measurement of the possibility to recruit a } \\
\text { new student (a lead) }\end{array}$ & CE.10.2 & CONSULTANTS E. \\
\hline $\begin{array}{c}\text { More accurate and efficient student } \\
\text { admissions process }\end{array}$ & CE.7.7, DU1.7 & $\begin{array}{c}\text { CONSULTANTS E., } \\
\text { DIRECTORS UFV }\end{array}$ \\
\hline Higher rates of student enrolment & CE.7.8 & CONSULTANTS E. \\
\hline
\end{tabular}

Table 5. Advantages of transformation for teaching.

\begin{tabular}{|c|c|c|}
\hline Advantage & Theme & Source \\
\hline $\begin{array}{l}\text { Data analysis applied to gaming activities } \\
\text { that are combined with traditional classes }\end{array}$ & CE.1.1 & CONSULTANTS E \\
\hline Control of attendance & CE.1.1 & CONSULTANTS E. \\
\hline $\begin{array}{l}\text { Assistants trained with answers to the } \\
\text { questions of teachers in forums and tutorials } \\
\text { in order to help students in real time } 24 / 7 \\
\text { without direct teacher intervention }\end{array}$ & CE.1.1 & CONSULTANTS E. \\
\hline $\begin{array}{l}\text { More automated evaluation systems, more } \\
\text { evaluations (continuous evaluation), and } \\
\text { greater fairness in the evaluations }\end{array}$ & CE.7.3 & CONSULTANTS E. \\
\hline $\begin{array}{c}\text { Continuous assistance and support for } \\
\text { teachers }\end{array}$ & CE.1.8 & CONSULTANTS E. \\
\hline $\begin{array}{l}\text { Teachers are more professional and more } \\
\text { satisfied with their work }\end{array}$ & CE.8.2 & CONSULTANTS E. \\
\hline $\begin{array}{l}\text { Choice of courses more aligned with the } \\
\text { student and helping them discover their } \\
\text { vocation }\end{array}$ & CE.1.7 & CONSULTANTS E. \\
\hline $\begin{array}{l}\text { Predictive models to analyse the possible } \\
\text { future academic performance of the student, } \\
\text { useful in the analysis and adjustment of } \\
\text { teaching strategies and performance }\end{array}$ & CE.1.7 & CONSULTANTS E. \\
\hline $\begin{array}{l}\text { Helping students identify their talents, } \\
\text { finding personal fulfilment through } \\
\text { overcoming relevant personal challenges }\end{array}$ & CE.1.7 & CONSULTANTS E. \\
\hline $\begin{array}{l}\text { Providing students with curricular } \\
\text { orientation and recommendations }\end{array}$ & CE.1.7, CE.7.4 & CONSULTANTS E. \\
\hline $\begin{array}{l}\text { Personalising course content according to the } \\
\text { tasks or "learning style" of students and the } \\
\text { knowledge and skills they need to acquire }\end{array}$ & CE.1.7 & CONSULTANTS E. \\
\hline $\begin{array}{l}\text { Move from studying a degree programme } \\
\text { towards learning modules personalised to } \\
\text { the learning needs of each student }\end{array}$ & CE.1.7 & CONSULTANTS E. \\
\hline $\begin{array}{l}\text { The student selects their teacher and subject } \\
\text { matter using artificial intelligence }\end{array}$ & CE.1.7 & CONSULTANTS E. \\
\hline
\end{tabular}


Table 5. Cont.

\begin{tabular}{|c|c|c|}
\hline Advantage & Theme & Source \\
\hline $\begin{array}{l}\text { The most important aspect is to help each } \\
\text { student discover their true vocation }\end{array}$ & CE.1.7 & CONSULTANTS E. \\
\hline Personalisation of learning tasks & CE.7.5 & CONSULTANTS E. \\
\hline Higher degree of student satisfaction & CE.7.6 & CONSULTANTS E. \\
\hline Better student experience & CE.7.9 & CONSULTANTS E. \\
\hline $\begin{array}{l}\text { Better education both physically and } \\
\text { virtually }\end{array}$ & CE.8.1 & CONSULTANTS E. \\
\hline $\begin{array}{c}\text { Students receive greater support to take } \\
\text { greater advantage of the university } \\
\text { experience }\end{array}$ & CE.8.2 & CONSULTANTS E. \\
\hline Better preparation for the working world & CE.8.3 & CONSULTANTS E. \\
\hline $\begin{array}{l}\text { A more accessible university for students } \\
\text { with disabilities }\end{array}$ & CE.8.4 & CONSULTANTS E. \\
\hline Self-guided learning for students & CE.9.6 & CONSULTANTS E. \\
\hline $\begin{array}{c}\text { Greater interaction among groups of } \\
\text { students }\end{array}$ & CE.1.1 & CONSULTANTS E. \\
\hline $\begin{array}{l}\text { Automation of evaluations: many evaluation } \\
\text { tasks can be automated and coordinated } \\
\text { with personalised tasks }\end{array}$ & CE.1.1 & CONSULTANTS E. \\
\hline $\begin{array}{l}\text { For e-learning virtual/attendance control, } \\
\text { remote examining, etc. }\end{array}$ & CE.1.1 & CONSULTANTS E. \\
\hline $\begin{array}{l}\text { Search for articles, papers, CVs, } \\
\text { bibliographies that could be related to a } \\
\text { specific search theme }\end{array}$ & CE.1.1 & CONSULTANTS E. \\
\hline $\begin{array}{l}\text { Optimisation of student transition to the } \\
\text { working world, developing models of } \\
\text { recommendation based on the data collection } \\
\text { by the students and the characteristics of the } \\
\text { positions offered by companies }\end{array}$ & CE.1.7 & CONSULTANTS E. \\
\hline $\begin{array}{c}\text { Use of data collected through LMS (Moodle, } \\
\text { Canvas, etc.) or biometric or geo-positioning } \\
\text { to evaluate the cognitive abilities and levels } \\
\text { of interrelation of each student }\end{array}$ & CE.1.7 & CONSULTANTS E. \\
\hline $\begin{array}{l}\text { Early detection of the risk of abandonment } \\
\text { based on performance and comments by } \\
\text { tutors to activate the processes to prevent the } \\
\text { loss or the student or to reorient their } \\
\text { programme }\end{array}$ & CE.1.7 & CONSULTANTS E. \\
\hline Prediction of student potential & CE.1.7 & CONSULTANTS E. \\
\hline $\begin{array}{c}\text { Attention and engagement of each student in } \\
\text { class through the analysis of classroom } \\
\text { camera images }\end{array}$ & CE.1.7 & CONSULTANTS E. \\
\hline New innovation projects & DU.1.1 & UFV DIRECTORS \\
\hline $\begin{array}{l}\text { Student support and prevention of } \\
\text { abandonment }\end{array}$ & DU.1.7 & UFV DIRECTORS \\
\hline $\begin{array}{l}\text { Control, oversight, and prevention of } \\
\text { infractions }\end{array}$ & DU.1.7 & UFV DIRECTORS \\
\hline Improved communication among students & DU.1.7 & UFV DIRECTORS \\
\hline
\end{tabular}


Table 5. Cont.

\begin{tabular}{|c|c|c|}
\hline Advantage & Theme & Source \\
\hline $\begin{array}{l}\text { Improved student support through learning } \\
\text { analytics }\end{array}$ & DU.1.7 & UFV DIRECTORS \\
\hline Data of candidates and alumni & DU.1.7 & UFV DIRECTORS \\
\hline $\begin{array}{l}\text { Identify student performance in different } \\
\text { courses in different degrees, marks at the } \\
\text { lower end of the course (module) }\end{array}$ & DU.1.7 & UFV DIRECTORS \\
\hline $\begin{array}{c}\text { Benefits of data for teachers: for their } \\
\text { evaluation by students, for research (with } \\
\text { oversight and follow-up of their published } \\
\text { work and impact) }\end{array}$ & DU.3.5 & UFV DIRECTORS \\
\hline $\begin{array}{l}\text { Benefits for students, including better } \\
\text { understanding of student needs, better } \\
\text { student selection for the university, } \\
\text { improved student orientation to identify } \\
\text { strengths and areas for improvement }\end{array}$ & DU.6.1 & UFV DIRECTORS \\
\hline $\begin{array}{l}\text { Benefits for teachers, including designing } \\
\text { better programmes and planning based on } \\
\text { greater information, identifying teacher } \\
\text { strengths and areas for improvement, } \\
\text { improved teacher-student relationship } \\
\text { through better information and } \\
\text { communication }\end{array}$ & DU.6.2 & UFV DIRECTORS \\
\hline $\begin{array}{l}\text { Being data-driven helps the university help } \\
\text { its students in many ways, including } \\
\text { improving their experience; enhancing } \\
\text { student growth in academic, social, and } \\
\text { personal terms; improving student selection }\end{array}$ & DU.7.1 & UFV DIRECTORS \\
\hline $\begin{array}{l}\text { Being data-driven helps teachers in their } \\
\text { work to transform students, improving } \\
\text { themselves and helping to improve others }\end{array}$ & DU.7.6 & UFV DIRECTORS \\
\hline $\begin{array}{l}\text { Transformation is necessary to help students: } \\
\text { in their user experience and learning } \\
\text { outcomes, with accurate, up-to-date } \\
\text { information about students }\end{array}$ & DU.7.2 & UFV DIRECTORS \\
\hline $\begin{array}{l}\text { Transformation promotes and encourages } \\
\text { innovation }\end{array}$ & DU.7.8 & UFV DIRECTORS \\
\hline
\end{tabular}

Table 6. Advantages of transformation for economy and strategy.

\begin{tabular}{ccc}
\hline Advantage in Economy & Theme & Source \\
\hline $\begin{array}{c}\text { One of the main reasons to make the effort for } \\
\text { transformation is that it offers economic benefits: } \\
\text { more revenues, more profits, lower costs } \\
\text { (automation, efficient management), with more } \\
\text { income from more students, leading to better results }\end{array}$ & CE.8.5 & CONSULTANTS E. \\
\hline Improved profitability (ROI, EBITDA) & DU.7.9 & UFV DIRECTORS \\
\hline Advantage in Strategy & Theme & Source \\
\hline
\end{tabular}

One of the main reasons to make the effort for

transformation is that failing to do so will mean falling behind competitors and being pushed out of the market. This is not something to merely consider, it must be done. 
Table 6. Cont.

\begin{tabular}{ccc}
\hline Advantage in Strategy & Theme & Source \\
\hline $\begin{array}{c}\text { One of the main reasons to make the effort for } \\
\text { transformation is that it offers strategic advantages, } \\
\text { including digitalisation into the culture of the } \\
\text { university, providing the university deep immersion } \\
\text { in digital transformation }\end{array}$ & CE.8.9 & CONSULTANTS E. \\
\hline $\begin{array}{c}\text { Becoming a very valuable tool if it becomes } \\
\text { ingrained in the culture }\end{array}$ & DU.7.9 & UFV DIRECTORS \\
\hline $\begin{array}{c}\text { Being data-driven furthers the mission of the } \\
\text { university (unifying pathways, providing continuity } \\
\text { to the project beyond individuals) and favours } \\
\text { competitiveness }\end{array}$ & DU.7.5 & UFV DIRECTORS \\
\hline $\begin{array}{c}\text { Transformation offers strategic value: avoiding } \\
\text { important errors, increasing collective business } \\
\text { intelligence, identifying market trends }\end{array}$ & DU.7.5 & UFV DIRECTORS \\
\hline
\end{tabular}

Table 7. Advantages of transformation for management.

\begin{tabular}{|c|c|c|}
\hline Advantage & Theme & Source \\
\hline $\begin{array}{l}\text { Automation of administration: automation of } \\
\text { processes and tasks in order to focus on teaching } \\
\text { and learning }\end{array}$ & CE.1.1 & CONSULTANTS E. \\
\hline $\begin{array}{l}\text { Campus management using AI, analytics on } \\
\text { operations, etc. }\end{array}$ & CE.1.1 & CONSULTANTS E. \\
\hline $\begin{array}{c}\text { Improvements from transformation in terms of } \\
\text { organisation and efficiency: more proactive, more } \\
\text { interaction between areas, automation of processes, } \\
\text { more digital interaction with the university and } \\
\text { coherence in these interactions (regardless of } \\
\text { channel), better internal organisation, more } \\
\text { efficiency }\end{array}$ & CE 7.1 & CONSULTANTS E. \\
\hline $\begin{array}{l}\text { Anticipating potential threats, analysing trends, } \\
\text { improved metrics of the organisation, anticipating } \\
\text { risks, measurement of results }\end{array}$ & CE.7.2 & CONSULTANTS E. \\
\hline Better experience for all stakeholders & CE.7.2 & CONSULTANTS E. \\
\hline $\begin{array}{l}\text { Improved communication, both internal (better } \\
\text { reporting, understanding of results, sharing } \\
\text { advances) and external (better communication with } \\
\text { schools, companies, and society) }\end{array}$ & CE.7.10 & CONSULTANTS E. \\
\hline $\begin{array}{l}\text { One of the main reasons to make the effort for } \\
\text { transformation is that offers improvements in } \\
\text { management: more efficiency and effectiveness, } \\
\text { better planning and control (measuring activities } \\
\text { and their impact), and creating a culture of constant } \\
\text { collective learning }\end{array}$ & CE.8.6 & CONSULTANTS E. \\
\hline $\begin{array}{l}\text { Improved decision-making, more simple, reliable, } \\
\text { effective, rapid, and much more accurate. Objective } \\
\text { decisions based on information (not intuition or } \\
\text { preconceptions); better decisions based on data from } \\
\text { different sources }\end{array}$ & $\begin{array}{l}\text { CE.7.2, } \\
\text { DU.4.7, } \\
\text { DU.3.6, } \\
\text { DU.8.4, } \\
\text { DU.8.11 }\end{array}$ & $\begin{array}{l}\text { CONSULTANTS AND } \\
\text { DIRECTORS UFV }\end{array}$ \\
\hline $\begin{array}{l}\text { Some improvements in management: automation of } \\
\text { processes, improvements in productivity, freeing up } \\
\text { time for employees to do other tasks }\end{array}$ & CE.9.6 & CONSULTANTS E. \\
\hline
\end{tabular}


Table 7. Cont.

\begin{tabular}{ccc}
\hline Advantage & Theme & Source \\
\hline $\begin{array}{c}\text { Optimisation of services for faculty on campus (bus } \\
\text { routes, optimum location of services, optimisation of } \\
\text { classroom use, etc.) }\end{array}$ & CE.1.1 & CONSULTANTS E. \\
\hline $\begin{array}{c}\text { Analysis of the effectiveness of marketing actions } \\
\text { by the university }\end{array}$ & CE.1.1 & CONSULTANTS E. \\
\hline $\begin{array}{c}\text { Forecast of market demand for the services offered } \\
\text { bata provides value in many different areas: to }\end{array}$ & CE.1.1 & CONSULTANTS E. \\
$\begin{array}{c}\text { understand the past and project into the future, new } \\
\text { business possibilities, new innovation projects, } \\
\text { expanding the scope of the mission, greater } \\
\text { efficiency, better reporting, improvements in } \\
\text { management }\end{array}$ & DU.1.1 & UFV DIRECTORS \\
\hline $\begin{array}{c}\text { Transformation can help improve communication, } \\
\text { making it more agile }\end{array}$ & DU.4.1 & UFV DIRECTORS \\
\hline
\end{tabular}

Improvements in management: lower costs (less
management, less bureaucracy) and more focus on
the mission, time savings, improved and more agile
budgeting with better control, more accurate
oversight of costs, improved personal development
(people analytics), better awareness of the market, $\quad$ DU.6.3
more agile processes with interconnected and
quality controls, greater transparency and
engagement with current realities in the university,
enriched discussions and communication based on
specific data

Improvements in the use and usefulness of data, including finding new sources of data that currently do not exist, new crosschecking of data with user-friendly tools to extract information and draw conclusions from data

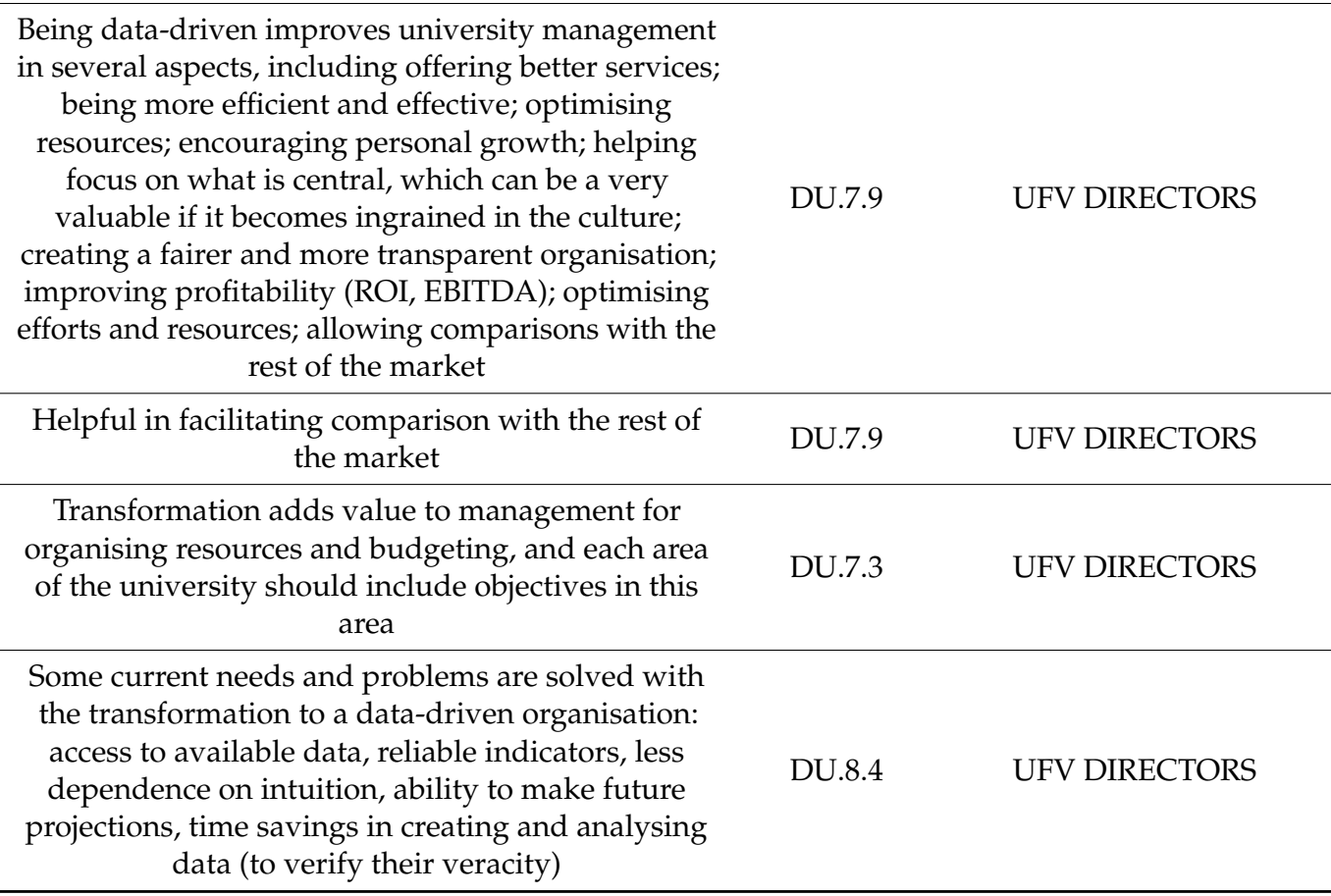


Table 8. Advantages of transformation for personnel.

\begin{tabular}{|c|c|c|}
\hline Team Growth & DU.1.1 & UFV DIRECTORS \\
\hline RRSS analysis, navigation, registers, etc. & CE.1.1 & E. CONSULTANTS \\
\hline $\begin{array}{l}\text { Digital identification systems for the entire } \\
\text { university career of the student }\end{array}$ & CE.1.1 & E. CONSULTANTS \\
\hline $\begin{array}{c}\text { One of the main reasons to make the effort for } \\
\text { transformation is to develop talent and build } \\
\text { team spirit through an analytic mentality and } \\
\text { use of data }\end{array}$ & $\begin{array}{l}\text { CE.8.12, } \\
\text { UD.1.1, } \\
\text { UD.7.9 }\end{array}$ & $\begin{array}{c}\text { E. CONSULTANTS UFV } \\
\text { DIRECTORS }\end{array}$ \\
\hline $\begin{array}{l}\text { Digital attribution models using game theory } \\
\text { (Shapley value) }\end{array}$ & CE.1.1 & E. CONSULTANTS \\
\hline $\begin{array}{l}\text { Analysis of CVs, revision of work, } \\
\text { research/documentation/bibliography, etc. }\end{array}$ & CE.1.1 & E. CONSULTANTS \\
\hline Building team spirit & UD.1.1 & UFV DIRECTORS \\
\hline $\begin{array}{c}\text { Enhanced development of personnel (people } \\
\text { analytics), greater authority of university } \\
\text { leadership }\end{array}$ & UD.6.3 & UFV DIRECTORS \\
\hline Encouraging personal growth & UD.7.9 & UFV DIRECTORS \\
\hline $\begin{array}{l}\text { Being data-driven can help people (people } \\
\text { analytics) in many ways, such as better job } \\
\text { performance and thus greater fulfilment, } \\
\text { improving the lives of people by having more } \\
\text { information about them (itinerary, location, } \\
\text { progress, expectations) and thus be able to help, } \\
\text { which also favours and enhances interrelations } \\
\text { and cooperation. }\end{array}$ & UD.7.2 & UFV DIRECTORS \\
\hline $\begin{array}{l}\text { Having data adds value and helps to lead by } \\
\text { having real information, not only intuition. } \\
\text { Information is highly valuable and integrating } \\
\text { information (both internal and external) builds } \\
\text { added value }\end{array}$ & UD.7.4 & UFV DIRECTORS \\
\hline $\begin{array}{l}\text { Providing value to people: serenity, reducing } \\
\text { stress, helping to be focussed, being able to } \\
\text { verify whether they are performing well, and } \\
\text { helps improve relationships within and between } \\
\text { teams, connecting areas with the same interests } \\
\text { and building relationships between teams }\end{array}$ & UD.7.4 & UFV DIRECTORS \\
\hline
\end{tabular}

Table 9. Advantages of transformation in teaching.

\begin{tabular}{ccc}
\hline \multicolumn{1}{c}{ Advantage } & Theme & Source \\
\hline $\begin{array}{c}\text { Study the levers that enhance institutional prestige } \\
\text { and increase it }\end{array}$ & CE.1.1 & E. CONSULTANTS \\
\hline $\begin{array}{c}\text { One of the main reasons to make the effort for } \\
\text { transformation is that it enhances the image of the } \\
\text { organisation (modernisation, attracting talented } \\
\text { students), improves competitiveness for the } \\
\text { university, enhances the image and prestige of the } \\
\text { UFV brand }\end{array}$ & CE.8.3 & E. CONSULTANTS \\
\hline $\begin{array}{c}\text { Measurement of the brand image and reputation } \\
\begin{array}{c}\text { Modelling the position of each university in public } \\
\text { rankings in order to climb up in the ranking }\end{array}\end{array}$ & CE.10.2 & E. CONSULTANTS \\
\hline
\end{tabular}


Improvements in management: This includes lower costs (less management, less bureaucracy) and more focus on the mission, time savings, improved and more agile budgeting with better control, more accurate oversight of costs, improved personal development (people analytics), better awareness of the market, more agile processes with interconnected and quality controls, greater transparency and engagement with current realities in the university, enriched discussions and communication based on specific data, greater authority of university leadership.

The research found that some universities are already benefiting from the advantages, as indicated in Table 1.

The results of the qualitative methodology of inductive thematic analysis used in this research cannot be extrapolated; however, what can be useful for other universities is the methodology, the identification of barriers and actions to overcome them, and the advantages transformation has to offer.

Regarding the degree of progress in the digitalisation of universities and highereducation institutions on a global level, this issue was only raised with the expert consultants in question 9. In this aspect, higher-education institutions can be classified into two groups: those originating as digital institutions (considered "digital natives") providing remote learning (synchronous and/or asynchronous) and those that did not ("classic" or traditional institutions), offering presential learning. For the former, digitalisation is obviously a fundamental aspect, whereas the latter may find themselves in different stages in this process. This reality may help traditional institutions realise the need to pursue digitalisation given that their competitors are digital natives. Although it may be considered that remote or distance learning and presential learning are two different markets, the COVID-19 pandemic has accelerated the appearance of a hybrid format (both remote and presential) in traditional institutions and is bridging the gap between the two models.

\section{Discussion}

As indicated in the previous section, the aim of this research was to identify the methodology for the transformation of UFV into a data-driven organisation. The research identified four phases (diagnostic, preparation, implementation, and improvements and optimisation) and provided the details and information on the content of each.

No studies were found that specifically and completely analysed the process of the transformation of a university into a data-driven organisation, neither in terms of teaching nor management, despite searching over 34,000 bibliographical references using the reading algorithm developed by Dr. César Moreno Pascual for his doctoral thesis (Moreno, 2017).

Many authors have proposed that the transformation process be divided into several phases [32], and many agree on the various phases or on the different steps within these phases as identified in this study. The phases were classified in order to facilitate the grouping of steps into a logical and chronological order for the purposes of this study. No doubt these can be organised differently with more or fewer steps. The structure presented here was chosen because of the commonalities with many other transformation projects in organisations, although the references mention other steps that may be useful to introduce.

\subsection{Diagnostic and Preparation Phases}

The bibliography is limited on how to conduct the diagnostic and preparation phases for the transformation of universities into data-driven organisations [33].

There is an extensive bibliography about these two phases of digital transformation in companies that mentions the aspects that are in line with the findings of the present study. These include ideas such as having a leader who firmly believes in transformation, driving and coordinating the project (Kotter, 1995), the definition of an action plan [34], talent and investment [35], cultural change (analytic mentality) [36], data governance [37], and preparing the team for transformation with training and support [38], and are reflected in the studies indicated in the footnotes below. 
There were points of divergence in the consideration of critical variables on the part of the two groups (these variables are: Technology, Analytic Mentality, Leadership and Data-Based Decision-Making and Improved Data Management). Although both groups considered these variables important, the EC (expert consultants) participants gave lower scores/ less importance to all of these, as shown in Table 10.

Table 10. Scoring of critical variables by the two groups of participants.

\begin{tabular}{ccccc}
\hline & EC Average & UD Average & Difference & Difference $\%$ \\
\hline Technolology & 7.6 & 9.6 & -2 & $-21 \%$ \\
AnalyticalMentality & 8.4 & 9.3 & -0.9 & $-10 \%$ \\
Leadership\&Decisions & 8.3 & 9.8 & -1.5 & $-15 \%$ \\
ImprovedDataManag & 9.0 & 9.6 & 0.6 & $-6 \%$ \\
\hline
\end{tabular}

The table provides the average scores out of 10 for the two groups of participants. The greatest differences were found in "technology" and "leadership and decision-making." Regarding technology, one of the participants of the EC group considered it "necessary but not the key" (theme EC.3.1). On leadership, one of the ECs noted that leadership "is not particularly necessary" (theme EC.3.3).

In the opinion of the authors, the lesser importance given by the EC to technology, leadership, and analytical mentality should be understood in relative terms: They gave less importance to these variables than the UD group but nevertheless regarded them as important to the transformation process.

\subsection{Implementation Phase}

Regarding the implementation of the transformation project, the findings of previous studies on the barriers and actions necessary for successful implementation are in line with the results of the present research. Barriers and actions to drive various aspects of the project forward include communication [34], economics [39], data management [40], leadership [41], mentality (Kotter, 1995), operational aspects [42], relation to long-term results (Kotter, 1995), technology [43] (this point can be also seen in the study by MinTIC and iNNpulsa Colombia in 2015), and support and training (The Irene Vázquez Chair, UFV, 2020), and are reflected in the studies indicated in the footnotes below.

It is interesting to note that when the results were analysed, there were few coincidences between the barriers suggested by the expert consultants and those suggested by the UFV directors.

There were coincidences in the following: first, economics (failing to provide an adequate budget); second, operations (the barrier presented by the organisational changes necessary for transformation); third, mentality (the lack of a business mentality in the academic world), and fourth and finally, the long-term nature of the results. The first was readily detectable by both groups as it is easy to suppose that a significant investment is required for this type of transformation. The second, although it was no surprise that the expert consultants were aware of the organisational changes required by transformation, it was surprising that some UFV directors were aware of these consequences. The researchers propose this may be due to the fact that UFV directors holding this opinion had experience with this type of transformation. Furthermore, the university directors received information on this during the course of the transformation. As for the third, the fact that both groups recognised this aspect underscores its significance. For the fourth, this may be due to the fact that the directors were aware of this issue because it is a common theme in management. It is also interesting that some UFV directors were aware of these changes and that the overall results are long term and thus may be able to overcome the frustrations that may arise.

It is also interesting to note that the UFV directors identified poor communication as a barrier, whereas expert consultants with experience in these transformation projects did not. 
Of all the barriers identified in the research, there are few that can be considered specific to the transformation within higher-education institutions or that were not found in other studies. Among these are the lack of a business mentality in the academic world (theme EC.4.2), an excessive workload that does not allow for the dedication of the time necessary for transformation (theme UD.9.1), and that the strategic plan must prioritise steps and clearly convey the idea that transformation will not be effective unless all these steps are coordinated avoid feelings of frustration with the process (theme EC.4.6).

In the opinion of the researchers, the first may be specific to a higher-education institution, but without generalising all institutions or all their employees, or remaining exclusively in this sector. Regarding the second and third, these barriers are not considered exclusive to the sector but are issues that must be addressed.

With regards to the barriers that were not identified by both the EC and UD groups, these may be due to the different professional profiles and experiences among the participants in each group.

As for the actions required to overcome barriers and resistance, the groups coincided more frequently in these aspects than in identifying the barriers; these coincidences may be due to the common experience of both groups and/or that these actions are simply logical. For the agreed suggestion regarding data management and having specific and accurate data, this view on the part of the UD group may be due to the need for some areas to have this type of data. The groups also agreed on the need to promote an analytic mentality through training and support. The coincidence may be due to the fact that the UFV directors were aware both of the importance of this mentality and the need for further development in this aspect.

As was the case with barriers to transformation, the UD group regarded good communication as an effective tool in overcoming resistance, whereas the expert consultants with experience in this type of transformations did not. Other actions proposed only by the UD group were the use of multi-disciplinary teams and the involvement of middle management as important players in the process. This may be due to the fact that it is habitual at UFV to create multidisciplinary teams for project management and that middle managers play an important role in the organigram of the university. In the opinion of the researchers, both communication and the other two actions mentioned present interesting opportunities for pushing the transformation project forward.

\subsection{Improvements}

The study found 96 improvements to the university in becoming a data-driven organisation, adding value both in terms of the quality of education and management. Some of these improvements are reflected in the analysed documents [44] and refer to a number of themes, such as improvements in eLearning [45], (many arising in the wake of the COVID19 pandemic and the need for remote learning) through the use of specific techniques of business intelligence applied to teaching (such as blockchain [46]), or improvements in education (some indicated in Table 1).

Studies were also found that refer to the use of data in the management of highereducation institutions. These improvements refer specifically to data security [47], fundraising and donations (University of California), increased student enrolment (Sinclair Community College), estimation of financial assistance for students (University of Oregon), ethics in the use of student data (García Peñalvo, 2023), cost savings (Arizona State University, which automated its purchasing), and time savings in management (California Community Colleges System is a post-secondary education system in California, USA. It is the largest post-secondary education system in the US with over 2.1 million students and often referred to as the CCCS. It is currently working on developing a shared model for a cloud-based ERP to rationalise processes and achieve economies of scale in the back-office. It is estimated that $\$ 1.96$ million in costs may be saved through this project) [48].

Other examples of improved management through transformation into a data-driven organisation are improvements in communication on issues of administration with stu- 
dents [49], plans for the digitalisation of all areas of the university [50], and the unification and interconnection of data from different areas such as marketing, sales, finance, human resources, student services, quality, and IT [51].

All of these themes mentioned by other authors coincide with the improvements detected in this research, although Tables 4-9 indicate further improvements found in this research.

It should be noted that Tables 4-9 contain 96 improvements obtained in the research, that is, their origin is in the opinions of the participants. It is true that some of the participants were not experts in digitisation (the group of university executives). That is why these advantages can be questioned. These are the ones listed in the DU topics. However, the advantages provided by the expert consultant participants were based on their real experience in organisational transformations and are catalogued in CE topics. In any case, it is interesting to note that some of the expert consultants had no experience in transforming educational organisations and that the advantages provided by them that are specific to an educational organisations might not be successful.

\subsection{Limitations, Doubts, and Self-Criticisms}

Few participants considered any possible negative consequences of digitalisation. Two of these may be the dehumanisation of decisions based entirely on data as well as the possible unethical use of data in modelling, interpretation, and privacy issues.

One doubt that can be raised about this study is that the university directors were asked about transformation to a data-driven organisation without many of them having experience or in-depth knowledge about change management or the use of data. This issue goes to the importance of university directors as leaders of the transformation process, a process that is already underway, and some of their opinions may be uninformed.

Another limitation to the study may be that some expert consultants did not have experience with transformation in higher-education institutions.

It is also interesting to note that the UFV directors identified poor communication as a barrier, whereas the expert consultants, with experience in these types of transformations, did not. The consultants also did not consider communication an important factor in implementation. However, many of the studies analysed and reflected in this section considered that correct and adequate communication is an important factor in the success of the transformation process.

There were several affirmations by some participants that others were not in agreement. For example, regarding the notion that higher-education institutions are slower in making use of data than other sectors, there were opinions both in favour and against (theme EC.9.1 Corroborates this Point, but EC.9.2 States the Contrary).

The same was the case with the notion that advances in the use of data by these institutions is more focussed on teaching than on management (theme EC9.2 affirms this while EC.9.4 affirms they are focussed on both).

Another point of discrepancy among the group of expert consultants was the degree of progress in the digital transformation of higher-education institutions. Thus, EC.9.1 affirmed that the advances in the use of data in higher-education institutions are slower than in other sectors, whereas EC.9.2 indicated the opposite. There was also no consensus among these participants on whether advances in the use of data are more commonly found in the area of teaching or of management (theme EC.9.3 affirms that more in teaching while ec.9.4 affirms that in both).

Another limitation of this study is that it does not provide an exhaustive description of all the steps necessary for the transformation of the university into a data-driven organisation.

Finally, another limitation of the research is that in the real world, variables not considered in this analysis may arise that can negatively influence the transformation of the university to be data driven.

The article reflects 26 barriers in Table 2, but they are certainly not all that could appear in a transformation process of this type. 
In order to face the barriers not reflected in this article, it is recommended that the transformation process be accompanied by experts with real experience in transformations of this type. Although it is true that today there are numerous consulting companies that can be hired for this issue, not many have people with concrete and real experience in the transformation of higher-education centres.

Another way to reduce this risk is to consult research and articles on this topic [52-54].

However, none of the articles are focused on the transformation of higher-education centres into data-driven organisations.

\section{Conclusions}

This paper aims to assist researchers in identifying the various steps universities should follow in the diagnostic, preparation, and implementation stages in the transformation to a data-driven organisation, as well as the barriers and facilitators of this transformation.

It also describes the advantages, conceptual and concrete, in the use of data in decisionmaking for both teaching and university management.

Author Contributions: Conceptualization, I.C.; methodology, I.C.; validation, I.C., C.G.-G. and V.F.R.; formal analysis, I.C.; investigation, I.C. and C.G.-G.; resources, I.C.; data curation, I.C.; writingoriginal draft preparation, I.C.; writing-review and editing I.C., C.G.-G. and V.F.R.; visualization, I.C., C.G.-G. and V.F.R.; supervision, C.G.-G. and V.F.R.; project administration, I.C. All authors have read and agreed to the published version of the manuscript.

Funding: This research was funded by the ETSII-Universidad Nacional de Educación a Distancia (UNED), Grant Number 2021/ICF01.

Institutional Review Board Statement: Not applicable.

Informed Consent Statement: Informed consent was obtained from all subjects involved in the study.

Data Availability Statement: Data supporting the reported results can be requested from the authors.

Conflicts of Interest: The authors declare no conflict of interest.

\section{Appendix A. Profiles of Participants}

Table A1. External consultants.

\begin{tabular}{cc}
\hline Position & Company \\
\hline Senior Software Engineer & Qilimanjaro Quantun Tech \\
\hline Senior Specialist & Deloitte Analytics \\
\hline Senior Manager & Deloitte Analytics \\
\hline Business Consultant Partner & Blue Insights \\
\hline Data Scientist Specialist & Deloitte Analytics \\
\hline Partner in the Analytics area & One of the “Big Four" \\
\hline Senior Manager & Deloitte Analytics \\
\hline Advisor and ex General Manager Conent \\
Decision Science
\end{tabular}


Table A1. Cont.

\begin{tabular}{cl}
\hline Position & Company \\
\hline Director General & GVA \\
\hline Data Engineer & Olympic Channel \\
\hline Senior Consultant & Deloitte Analytics \\
\hline Manager & Deloitte Analytics \\
\hline Partner of Analytics & Deloitte Analytics \\
\hline
\end{tabular}

Table A2. UFV directors.

\begin{tabular}{cc}
\hline Position & University \\
\hline $\begin{array}{c}\text { Director of Business Analytics and the Integral } \\
\text { Leadership Programme }\end{array}$ & Universidad Francisco de Vitoria \\
\hline Vice-rector for Comprehensive Education & Universidad Francisco de Vitoria \\
\hline General Secretary & Universidad Francisco de Vitoria \\
\hline $\begin{array}{c}\text { General Director of User Experience. } \\
\text { Ex-partner at KPMG }\end{array}$ & Universidad Francisco de Vitoria \\
\hline Manager & Universidad Francisco de Vitoria \\
\hline Director of the Online Unit & Universidad Francisco de Vitoria \\
\hline Director of BA and Gastronomy & Universidad Francisco de Vitoria \\
\hline Vice-rector of Faculty of Academic \\
Organisation & Universidad Francisco de Vitoria \\
\hline Former Dean of Education and Psychology & Universidad Francisco de Vitoria \\
\hline Director of Digital Evolution & Universidad Francisco de Vitoria \\
\hline Director of the Irene Vázquez Chair & Universidad Francisco de Vitoria \\
\hline General Director of University Recruitment \\
and Information & Universidad Francisco de Vitoria \\
\hline Expert in Learning & Universidad Francisco de Vitoria \\
\hline
\end{tabular}

\section{Appendix B. Information about the Interviews}

Table A3. Information about the interviews with the expert consultants.

\begin{tabular}{cccc}
\hline $\begin{array}{c}\text { Participant } \\
\text { External Consultant }\end{array}$ & Duration of the Interview & Sent Codes of the Interview & Other Actions \\
\hline 1 & $1 \mathrm{~h} 5 \mathrm{~min}$ & Yes & Call to clarify certain doubts \\
\hline 2 & $55 \mathrm{~min}$ & yes & Call to clarify certain doubts \\
\hline 3 & $1 \mathrm{~h} 15 \mathrm{~min}$ & yes & Call to clarify certain doubts \\
\hline 4 & $1 \mathrm{~h} 5 \mathrm{~min}$ & yes & Call to clarify certain doubts \\
\hline 5 & $1 \mathrm{~h}$ & yes & Call to clarify certain doubts \\
\hline 6 & $1 \mathrm{~h} 10 \mathrm{~min}$ & yes & yes \\
\hline 7 & $55 \mathrm{~min}$ & yes & yes \\
\hline 8 & $1 \mathrm{~h} 5 \mathrm{~min}$ & yes & yes \\
\hline 10 & $1 \mathrm{~h} 10 \mathrm{~min}$ & yes & Call to clarify certain doubts \\
\hline 12 & $1 \mathrm{~h}$ & yes & yes \\
\hline 14 & $1 \mathrm{~h} 5 \mathrm{~min}$ & &
\end{tabular}


Table A4. Information about the interviews with the UFV directors.

\begin{tabular}{cccc}
\hline $\begin{array}{c}\text { Participant Director at } \\
\text { Universidad Francisco de Vitoria }\end{array}$ & Duration of the Interview & Sent Codes of the Interview & Other Actions \\
\hline 1 & $1 \mathrm{~h} 15 \mathrm{~min}$ & yes & Call to clarify certain doubts \\
\hline 2 & $1 \mathrm{~h} 20 \mathrm{~min}$ & yes & Call to clarify certain doubts \\
\hline 3 & $1 \mathrm{~h} 20 \mathrm{~min}$ & yes & Call to clarify certain doubts \\
\hline 4 & $1 \mathrm{~h} 10 \mathrm{~min}$ & yes & \\
\hline 5 & $1 \mathrm{~h} 15 \mathrm{~min}$ & yes & yes \\
\hline 6 & $1 \mathrm{~h} 20 \mathrm{~min}$ & yes & Call to clarify certain doubts \\
\hline 7 & $1 \mathrm{~h} 30 \mathrm{~min}$ & yes & Call to clarify certain doubts \\
\hline 8 & $1 \mathrm{~h}$ & yes & yes \\
\hline 10 & $1 \mathrm{~h} 5 \mathrm{~min}$ & yes & yes \\
\hline 13 & $1 \mathrm{~h} 20 \mathrm{~min}$ & yes & \\
\hline
\end{tabular}

\section{Appendix C. Questions for UFV Directors}

QUESTION 1: What do you believe are the most important and essential aspects of the transformation of UFV into a data-driven organisation? What will be the key results of this transformation?

QUESTION 2: How do you feel in relation to the transformation project (distant, close, motivated, expectant, confused, etc.)?

QUESTION 3: How would you imagine your day-to-day work if you were to have all the data available and were working in this way? What would be different?

QUESTION 4: How would you describe an analytical mentality and data-based decision-making? What would be the attitudes, behaviour, and competences of these individuals? Would they be prepared?

QUESTION 5: Let us assume that the key aspects of transforming the university into a data-driven organisation are:

- Technology: necessary to make information useable and accurate (artificial intelligence, user experience, single data lake);

- Analytic mentality: a data-based culture with the necessary competences;

- Leadership and decision-making: based on data (data controls and KPIs);

- Improved data management (data quality, ethics, improved processes).

With these, accurate and quality data can be collected with the necessary technology and analytic mentality to make use of this data to have a fuller picture of reality, improved decision-making, and management in the service of individuals and their growth.

Score from 1 to 10 your level of agreement with aspects a, b, c, and d above, and comment on whether there are any other aspects you believe are essential to transformation.

QUESTION 6: In your opinion, which are the three most important reasons that justify the effort to transform the university into a data-driven organisation?

QUESTION 7: What value do you believe this project brings to your area specifically?

QUESTION 8: How do you believe you should contribute to the project and to what extent do your feel prepared? What would you need to feel prepared?

QUESTION 9: What are the most significant difficulties/barriers to the project? How can they be overcome? 


\section{Appendix D. Questions for Expert Consultants}

QUESTION 1: Universities are now using data to improve their decision-making, both for their students and in business and management aspects.

Examples of the use of data in American universities:

- Measuring student performance, providing guidance and assistance to those who need it, allowing for early intervention and help for students before it is too late;

- Student admissions process to select the most promising students and predict their potential;

- To support student enrolment and increase the number of students at the university;

- To raise more donations (for American universities, donations are an important source of revenue);

- The use of information from LMS (Canvas, Moodle, etc) to support students and improve learning outcomes;

- The use of biometric data to understand patterns of stress and attention among students, such as a biometric bracelet tracking electrical charges in the sympathetic nerves of the student (by analysing the data from each bracelet, teachers can determine the level of commitment of the student (or lack thereof) in real time);

- In construction projects to optimise the use of space;

- Blockchain for security and veracity of accreditations;

- Detection of security threats to the university network;

- Retention of students and increased graduation rates.

In what specific areas, and using what methodology (econometrics, neural networks, etc.), do you think this data can help the university in addition to the examples listed above?

QUESTION 2: Is it necessary for a university team to have an analytic mentality/experience in the use of date to take advantage of data? How can this mentality be inculcated if necessary? What attitudes, behaviours, and competences would people need?

QUESTION 3: As an initial hypothesis, the key areas in the transformation of a university into a data-driven organisation are:

- Technology: necessary to make information useable and accurate (artificial intelligence, user experience, single data lake);

- Analytic mentality: a data-based culture with the necessary competences;

- Leadership and decision-making: based on data (data controls and KPIs);

- Improved data management (data quality, ethics, improved processes).

With these, accurate and quality data can be collected with the necessary technology and analytic mentality necessary to make use of these data in having a fuller picture of reality, and improved decision-making and management in the service of individuals and their growth.

Score from 1 to 10 your level of agreement with aspects a, b, c, and d above, and comment on whether there are any other aspects you believe are essential to transformation.

QUESTION 4: What are the most significant difficulties/barriers to the project? How can they be overcome?

QUESTION 5: What does a university need to be prepared for this change?

QUESTION 6: Do you think university staff need the support of an external team? What kind of professionals (internal or external) are necessary for this transformation?

QUESTION 7: How would you imagine the day-to-day work of a data-driven university if all the data were available and being used in this way? What would be different?

QUESTION 8: In your opinion, which are the three most important reasons that justify the effort to transform the university into a data-driven organisation?

QUESTION 9: Higher-education institutions, such as universities, have been implementing the use of data for some time, but not as quickly as they should and not as quickly as in other sectors. Do you agree with this statement? Why?

Advances are mainly focussed on education rather than management. Do you agree? 
QUESTION 10: In your experience as a consultant, have you helped educational institutions make use of data? Which ones?

\section{Appendix E. Methodology of Transformation, Grouping Themes from the Two Groups of Participants \\ Appendix E.1. Diagnostic and Starting Point of the University Prior to Beginning the Transformation Process}

- $\quad$ Conduct an in-depth diagnostic of the starting point. EC.5.5, EC.8.10

Carry out a diagnostic on the way of working (planning, processes, reflection). UD1.12

- Identify the available professionals in the university who are apt for transformation. EC.6.3

- Test the attitude and preparation and the degree of importance given to transformation of the entire management team. Transformation must be a top priority for all directors, but it is not for all. There are also varying feelings and perceptions on the degree of progress. UD.2.1, UD.2.7, UD.8.1, UD.2.2

- $\quad$ Conduct a diagnostic of the analytical mentality of the university team. UD.4.4

- Analyse the state of the technical aspect of the transformation into a data-driven organisation at the start of the project. Data cannot be accessed depending on technicians even when there are effective systems provided but poorly used. The process of ordering and connecting different databases and of transforming information boards for users has begun. UD.2.3, UD.7.7

- Conduct a diagnostic of the resistance to change and the possible barriers that may hinder transformation. There will not be a great deal of resistance to change if this is well communicated and not interpreted as merely more bureaucratic work. UD.2.4 UD.2.6

\section{Appendix E.2. Preparation for Transformation}

- Define the project management team (to direct and coordinate change) made up of:

- $\quad$ The rector as the leader of the project;

- $\quad$ Project manager (member of the management committee);

- Management committee: driving the project forward in all areas;

- $\quad$ Experts (generally external) in transformation and technical aspects, with a technical profile (data science, data engineering, expert in user experience, chief data officer), but also with experience in profound changes, preferably in higher-education institutions;

- University support team: technical personnel with a deep knowledge of the university;

- $\quad$ Ambassadors: team to support and promote the project with talent, dedicated to the project and leaders in their areas;

- $\quad$ Data department: consisting of specialists who support and promote an analytic mentality, answering questions, giving continuous training, and helping to define the controls, use of tools and access to the data necessary for each area.

EC.5.1, EC.2.4, EC.5.2, EC.3.5, EC.4.22, EC.5.8, EC.1.6, EC.3.6, EC.6.1, EC.6.2, EC.6.3, EC.6.4, EC.6.5, EC.6.6, EC.6.7, UD.5.6.

- Design an action plan that includes clear objectives, adequate budget for the entire process, and gradual transformation. Identify the objectives of transformation with those at the centre of the process. UD.1.13, EC.5.11, EC.5.6.

- Analytic mentality:

- Implement an analytic mentality. This is a key issue and will require prior knowledge (mathematics, tools, etc.), training (pedagogy) adapted to the different positions, and training in workshops to acquire specific competences with 
support, conveying confidence in data through quick wins. A cultural change is necessary, with the feeling that an analytic mentality helps filter a great deal of information reaching users and with adequate tools for data processing and visualisation. EC.2.2, EC.2.3, EC.2.1, EC.3.2 UD.4.2, UD.1.11, UD.4.5, UD.4.6, UD.5.4.

- Understanding clearly what an analytic mentality is: consisting of the user having the capacity for analysis and trust in data; the ability to understand, access, and work with data; and analysing and making decisions based on data, trusting in data and being business savvy. UD.1.11, UD.4.3, UD.4.1.

- Invest in the necessary technology. A significant investment in technology is required (large company EUR 3 million, small company from EUR 500,000 to EUR 700,000): data architecture, hardware and software, visualisation tools, integrating internal and external data networks, creating new data, among others, such as data lakes, storage systems, technological architecture, and hardware. EC.5.3, EC.1.9, EC.3.1, UD.1.5, UD.1.3, UD.5.12, UD.5.6.

- Detection and preparation of critical variables for transformation: technology, analytic mentality, leadership and decision-making leadership, and decision-making and improved data management. These are interrelated. Leadership and analytic mentality may be the most significant aspects, with technology subject to all the rest. The evaluation of the expert consultants of the four critical variables (out of 10) was as follows: technology (7.6), analytic mentality (8.4), leadership and decisionmaking (8.3), and improved data management (9.0). The evaluation of the university directors of the four critical variables (out of 10) was as follows: technology (9.6), analytic mentality (9.3), leadership and decision-making (9.8), and improved data management (9.6). EC.3.7, UD.5.3, UD.5.2.

- Having a data processing and data visualisation tool (critical variable):

- Having a data visualisation tool: The visualisation tool is considered one of the most critical issues; it must be user-friendly, reliable, and pedagogical, with different user levels and allowing data to be analysed and conclusions drawn. UD.5.6, UD.1.9, UD.1.4, UD.5.7, UD.7.9, EC.2.8.

- Data creation, accessibility, governance, and quality. Correct data management and architecture: the necessary data, with a single source and interpretation of the data. UD1.6, EC.5.4, EC.7.8.

- $\quad$ Prepare the team to face and accept the cultural change that transformation represents.

- Prepare the team to face and accept the cultural change that transformation represents, working to anticipate possible resistance and using levers to drive the project forward, such as communicating the importance of the change and the active engagement of the management team, and that the change takes place within everyone, developing an analytic mentality and having teams with the appropriate profiles. EC5.9, EC.5.10, EC.1.12, EC.2.6, EC.4.20, UD.2.3, UD.8.3.

- Provide directors with training in management in order to understand the dimensions of the change and how to manage it.

- Tools, technology, and data analysis for all users.

- Prepare the entire university team to be able to exchange knowledge and information and thus enrich and improve the management of their areas (critical variable). UD.1.2, UD.5.1, UD.5.6

- Define/review/update processes to ensure they are logical and coherent and can be assisted using data. UD.1.14, UD.5.6

\section{Appendix E.3. Implementation of Transformation}

The barriers are outlined in Table 2, and the possible actions to overcome them can be found in Table 3. 
Appendix E.4. Advantages for a Data-Driven University (94 Advantages), Grouped by Areas Where There Is Added Value

These advantages are outlines in Tables 4-9.

Appendix E.5. Other Observations of Interest by the Participants

- $\quad$ Strategy: competitors on a global scale, both online and presential (EC.1.11);

- Higher-education institutions (HEI) are slower in making advances in the use of data, as demonstrated by the COVID-19 pandemic, when many universities were unprepared compared to other sectors (EC.9.1);

- Taking advantage of advances in the use of data is slower in higher-education institutions (HEI) than in other sectors (for example, online education through MOOCS) (EC.9.2);

- Advances in the use of data in higher-education institutions is more focussed on teaching than management (CE9.3);

- Advances in the use of data by higher-education institutions are seen in both education and management (working with ERPs), although they generally remain far from being data-driven organisations (EC.9.4);

- Transformation to being a data-driven organisation is slower in higher-education institutions than in other sectors due to a number of causes, such as it being easier to measure ROI in other sectors, lack of data, unawareness of the value data has to offer, ethical and privacy issues, lack of historical data, being a very traditional sector resistant to change, and being a less competitive sector (EC.9.5);

- Digitalisation of higher-education institutions is found in digital-native organisations but not in traditional centres (EC.9.7);

- Digitalisation has advanced in higher-education institutions in research and teacher training but is not habitual in the area of management (EC.9.8);

- $\quad$ There would be more students but fewer presential students (EC.7.7);

- The use of data must become an absolute priority (EC.7.9);

- With the number of resources available online to learn with the best professors in each field, what can a local and campus-based university offer its students to encourage them to enrol (EC.8.7)?

- Digitalisation is more helpful in remote learning and with a different organisation of presential education (EC.8.8).

\section{Appendix E.6. Prior Experience of Consultants in Educational Institutions}

The majority of participants have supported the transformation of higher-education institutions into data-driven organisations.

\section{References}

1. McKinsey Digital. Five Moves to Make during a Digital Transformation. Available online: https://www.mckinsey.com/businessfunctions / mckinsey-digital/our-insights / five-moves-to-make-during-a-digital-transformation (accessed on 1 November 2021).

2. Diana, G.O. Digital Transformation: It's Time. Educ. Rev. 2020, 3. Available online: https://er.educause.edu/articles/2020/8 / digital-transformation-its-time (accessed on 1 September 2021).

3. César, M.P. Conceptualización de Áreas de Conocimiento en Economía y Empresa: Una Metodología de Revisión de Síntesis Integradora Basada en Redes Bi-Relacionales de Citas Bibliográficas. Ph.D. Thesis, Comillas Pontifical University, Madrid, Spain, 2017. Available online: https:/ / repositorio.comillas.edu/xmlui/handle/11531/26431 (accessed on 1 September 2021).

4. Sun, K.; Mhaidli, A.H.; Watel, S.; Brooks, C.A.; Schaub, F. It's my data! Tensions among stakeholders of a learning analytics dashboard. In Proceedings of the 2019 CHI Conference on Human Factors in Computing Systems, Scotland, UK, 4-9 May 2019.

5. Attaran, M.; Stark, J.; Stotler, D. Opportunities and Challenges for Big Data Analytics in US Higher Education: A Conceptual Model for Implementation; California State University: Long Beach, CA, USA, 2018. [CrossRef]

6. Universidad Carlos III de Madrid. Available online: https://www.uc3m.es/inicio (accessed on 1 September 2021).

7. Acevedo, A. Modelo de Madurez Para la Transformación Digital; Idom, iNNpulsa Colombia-Desarrollo Empresarial, MINTICSubdirección de Comercio Electrónico, 2018. Available online: https://www.centrosdetransformaciondigital.gov.co/695/articles78552_archivo_pdf.pdf (accessed on 1 September 2021). 
8. BarNir, A.; Gallaugher, J.M.; Auger, P. Business process digitization, strategy and the impact of firm age and size: The case of the magazine publishing industry. J. Bus. Ventur. 2003, 18, 789-814. [CrossRef]

9. Bettis, R.A.; Hitt, M.A. The new competitive landscape. Strateg. Manag. J. 1995, 16, 7-19. [CrossRef]

10. Blackburn, S.; LaBerge, L.; O’Toole, C.; Schneider, J. Digital Strategy in a Time of Crisis. April 2020. McKinsey Digital. Available online: https:/ / kolnegar.ir/wp-content/uploads/2020/07/Digital-strategy-in-a-time-of-crisis.pdf (accessed on 1 September 2021).

11. Bradley, C.; Hirt, M.; Smit, S. Strategy to Beat the Odds, McKinsey 2018. Available online: McKinsey.com (accessed on 1 September 2021).

12. Gupta, M.; George, J.F. Toward the development of a big data analytics capability. Inf. Manag. 2016, 53, 1049-1064. [CrossRef]

13. Cultura Data Driven: Cómo Gestionar los Datos de los Clientes de Forma Eficaz. Available online: https://www.elconfidencial. com/empresas/2020-02-11/gobierno-del-dato-chief-data-officer-deloitte-bra_2448288/ (accessed on 1 September 2021).

14. Instituto Tecnológico de Aragón (ITAINNOVA). Guía Para la Transformación Digital de Pymes Industriales; Instituto Tecnológico de Aragón (ITAINNOVA): Zaragoza, Spain, 2018.

15. Pagani, M.; Pardo, C. The impact of digital technology on relationships in a business network. Ind. Mark. Manag. 2017, 67, 185-192. [CrossRef]

16. Ringberg, T.; Reihlen, M.; Rydén, P. The technology-mindset interactions: Leading to incremental, radical or revolutionary innovations. Ind. Mark. Manag. 2019, 79, 102-113. [CrossRef]

17. Ritter, T.; Pedersen, C.L. Digitization capability and the digitalization of business models in businessto-business firms: Past, present, and future. Ind. Mark. Manag. 2020, 86, 180-190. [CrossRef]

18. Ross, J. Don't confuse digital with digitization. MIT Sloan Manag. Rev. 2017, 58, 2.

19. Simmons, G.; Palmer, M.; Truong, Y. Inscribing value on business model innovations: Insights from industrial projects commercializing disruptive digital innovations. Ind. Mark. Manag. 2013, 42, 744-754. [CrossRef]

20. The Digital Transformation Insight Report; CDW, 2018. Available online: https://www.cdw.com/content/cdw/en/ orchestration/digital-transformation-report.html (accessed on 1 September 2021).

21. The New Digital Edge: Rethinking Strategy for the Postpandemic Era. McKinsey Quarterly, 26 May 2021. Available online: https:/ / www.mckinsey.com/business-functions/mckinsey-digital/our-insights/the-new-digital-edge-rethinking-strategyfor-the-postpandemic-era(accessed on 1 August 2021).

22. Venkatraman, N. IT-enabled business transformation: From automation to business scope redefinition. Sloan Manag. Rev. 1994, $35,73-87$.

23. Weill, P.; Woerner, S. What Is Your Digital Business Model? Six Questions to Help You Build the Next-Generation Enterprise; Harvard Business School Press: Boston, MA, USA, 2018.

24. Many Sources Make Reference to These Phases of Digital Transformation. Available online: https://www.winecta.com/fasesproceso-transformacion-digital/ (accessed on 1 September 2021).

25. Plan Estratégico UFV 18-23. Available online: https://www.ufv.es/wp-content/uploads/2018/01/plan-estrategico-18-23-ufv. pdf (accessed on 1 September 2021).

26. John, P.K. Harvard Business Review (HBR) Leading Change: Why Transformation Efforts Fail. Available online: https:/ /hbsp. harvard.edu/product/R0701J-PDF-ENG (accessed on 1 September 2021).

27. Carpenter, C.; Suto, M. Qualitative Research for Occupational and Physical Therapists: A Practical Guide; Black-Well Publishing: Hoboken, NJ, USA, 2008.

28. Turner-Bowker, D.M.; Lamoureux, R.E.; Stokes, J.; Litcher-Kelly, L.; Galipeau, N.; Yaworsky, A.; Solomon, J.; Shields, A.L. Informing a priori sample size estimation in qualitative concept elicitation interview studies for clinical outcome assessment instrument development. Value Health 2018, 21, 839-842. [CrossRef] [PubMed]

29. Expert in Change Management in Organisations; Irene Vázquez Chair of the Universidad Francisco de Vitoria: Madrid, Spain, 2019.

30. Braun, V.; Clarke, V. Using thematic analysis in psychology. Qual. Res. Psychol. 2006, 3, 77-101. [CrossRef]

31. Robert Wood Johnson Foundation. The Qualitative Research Guideline Project. Available online: http://www.qualres.org/ HomeLinc-3684.html (accessed on 1 August 2021).

32. Las 5 Fases de la Transformación Digital. Available online: https:/ / www.ealde.es/fases-transformacion-digital/ (accessed on 1 August 2021).

33. La UE, Una Universidad Data Driven. Available online: https://youtu.be/V6eTCJ4W8Jc (accessed on 1 August 2021).

34. Beer, M.; Eisenstat, R.A.; Spector, B. Why change programs don't produce change. Harv. Bus. Rev. HBR 1990, 68, $158-166$.

35. Beer, M.; Nohria, N. Cracking the code of change. Harv. Bus. Rev. HBR Crack 2000, 78, 133-141.

36. Cabezas-González, M.; Casillas-Martín, S.; García-Peñalvo, F.J. The digital competence of pre-service educators: The influence of personal variables. Sustainability 2021, 13, 2318. [CrossRef]

37. Zamora, J.; Herrero, P. Preparado para sacar provecho a la inteligencia artificial? Rev. IESE 2018, 65. Available online: https: //www.iesepublishing.com/preparado-para-sacar-provecho-a-la-inteligencia-artificial-espanol.html (accessed on 1 August 2021).

38. Irene Vázquez. Modelo Dialógico Para Acompañar la Transformación Organizacional: Propuesta de Valor y Sintesis del Modelo; The Universidad Francisco de Vitoria: Madrid, Spain, 2020. 
39. MinTIC and iNNpulsa, Colombia, 2015. Available online: https://vdocument.in/mintic-colombia-2015.html (accessed on 1 September 2021).

40. Krawitz, M.; Law, J.; Litman, S. How Higher-Education Institutions can Transform Themselves Using Advanced Analytics; McKinsey: Rosemont, IL, USA, 2018.

41. Deakin, J.; LaBerge, L.; O’Beirne, B. Five Moves to Make during a Digital Transformation. McKinsey Digital. Available online: Mckinse.com (accessed on 1 August 2021).

42. Deakin, J.; LaBerge, L.; O’Beirne, B. McKinsey \& Company. Available online: Mckinsey.com (accessed on 12 May 2021).

43. Diener, F.; Špaček, M. Digital transformation in banking: A managerial perspective on barriers to change. Sustainability 2021, 13, 2032. [CrossRef]

44. Your A-Z Guide to Data in Higher Education. A Quick Overview of the Data Techniques That Higher Education Professionals Need to Know. Available online: www.edudatasummit.com/ (accessed on 1 August 2021).

45. García-Peñalvo, F.J. Avoiding the dark side of digital transformation in teaching. an institutional reference framework for elearning in higher education. Sustainability 2021, 13, 2023. [CrossRef]

46. Edublocs. Available online: www.edublocs.org (accessed on 1 August 2021).

47. Bartolomé, A.; Lindín, C. Instituto de Investigación en Educación, Universitat de Barcelona, Spain. Available online: https: / / orcid.org/0000-0002-8096-8278 (accessed on 1 August 2021).

48. California Community Colleges. Available online: https://www.cccco.edu/ (accessed on 4 August 2021).

49. UNED is a Pioneer in Distance Learning and These has Allowed It to Take the Lead in Becoming a Data-Driven University, Both in Administration and in Teaching. Available online: https://app.uned.es/portal/admision-matricula-por-internet (accessed on 1 August 2021).

50. Universidad Carlos III: Annual Reports 2018 and 2019. Available online: https://www.albizu.edu/wp-content/uploads/2021/0 2/UCA-Single-Audit-FS-2018-Traceable.pdf (accessed on 1 August 2021).

51. Universidad Europea. Available online: https://www.es.logicalis.com/noticias/analytics-universidad-europea/ (accessed on 1 August 2021).

52. Gupta, V.; Madhav, S.; Santhanam, N.; Tosato, P. How to Remove the Obstacles to Accelerated Performance Transformation; McKinsey \& Company: Chicago, IL, USA, 2018.

53. Vela, A. Difficulties of Digital Transformation for Companies and Workers. INESEM Digital Magazine. Available online: https:// revistadigital.inesem.es/orientacion-laboral/dificultades-de-la-transformacion-digital-para-empresas-y-trabajadores/ (accessed on 1 August 2021).

54. The 7 Most Common Mistakes in Digital Transformation. Asepeyo Blog. Available online: https://www.asepeyo.es/blog/7errores-mas-comunes-transformacion-digital/ (accessed on 1 August 2021). 